\title{
Justice from the Ground Up: Distributive Inequities, Grassroots Resistance, and the Transformative Politics of the Environmental Justice Movement
}

\author{
Sheila Foster $\dagger$
}

In this Article, Professor Foster examines the environmental justice movement from the "ground up"-from the perspective of the predominantly poor, African-American residents of Chester, Pennsylvania who attempted to stop the clustering of waste facilities in their community. From this perspective, Professor Foster evaluates the manner in which the phenomenon of environmental injustice is framed, the efficacy of reforms in environmental decision-making processes, and the strategies and possibilities of grassroots efforts in achieving environmental justice. She argues that the distributive paradigm that often frames discussions of environmental injustice obscures the mechanisms and processes underlying inequitable outcomes, thwarting a full understanding of the phenomenon. Case studies such as Chester, however, illustrate that disproportionate exposure to environmental hazards result from a set of ongoing social processes that structure the political economy of poor communities of color. These grassroots struggles provide a window into the social relations and processes underlying distributive inequities and, thus, assist reformers in identifying the types of policy reforms likely to help achieve environmental justice. Professor Foster argues that

\section{Copyright $\odot 1998$ California Law Review, Inc.}

$\dagger$ Associate Professor of Law, Rutgers School of Law-Camden, New Jersey. The author expresses her sincere appreciation to the following people for reading and commenting on this Article at various stages of its development: Luke Cole, Roger Dennis, Giovanna Di Chiro, David Frankford, Angela Harris, Craig Oren, Jesse Ribot, Neil Smith, the 1996-1997 fellows at the Center for Critical Analysis of Contemporary Culture (CCACC) in New Brunswick, New Jersey, and the 1997 summer interns at the Center for Race, Poverty and the Environment in San Francisco, Califomia. This Article also benefited tremendously from the expert research assistance of Henry Komansky. This Article was supported both by the author's year-long fellowship with CCACC, which was partially funded by the Rockefeller Foundation, and a research grant from Rutgers Law School. The author also extends her sincere gratitude to Chester Residents Concerned for Quality of Life, particularly Zulene Mayfield and Jerome Balter, Esq. Finally, the author thanks Elizabeth Linette for her continued support throughout the process of writing this Article. 
achieving environmental justice requires that siting reforms take both social structure and process seriously. She, however, concludes that while siting reform is necessary to achieve environmental justice, it should not displace the kind of transformative political action currently taking place in communities such as Chester. This political action is crucial to marginalized communities hoping to gain access and contribute to the policy- and decision-making processes that affect their material interests.

\section{INTRODUCTION}

The environmental justice movement is one of the fastest growing social justice movements in the United States. The movement has emerged from a primarily local, grassroots response to the presence and continued siting of hazardous waste facilities in poor communities and communities of color. For the last two decades, these communities have fought back against the injustice they perceive permeates environmental decision-making. In doing so, they seek justice in environmental policymaking and administration.

What is the injustice they experience? What is the justice they seek? There is no clear-cut answer to such questions, especially given the diversity of the various local struggles. Any attempt to answer such theoretically complex questions must, however, consider the movement at its source. As many books on the subject illustrate, grassroots struggles form the core of any epistemological understanding of the movement and the content of its claims.' By studying the movement at its source and talking to those actually leading these struggles, we can begin to understand the normative content of their claims of injustice and their corresponding struggle for justice.

Both national and regional studies have attempted to "measure" the phenomenon of environmental injustice. ${ }^{2}$ These studies have both benefited and imperiled the movement. While studies documenting the connection between race and environmental hazards raised national consciousness about local struggles, they also begged for further examination of the underlying phenomenon. As Iris Marion Young warns,

1. See, e.g., Confronting Environmental Racism: Voices from the Grassroots (Robert D. Bullard ed., 1993); FACES of ENvironmental RACISM: CoNFronting IssUES of Global Justice (Laura Westra \& Peter S. Wenz eds., 1995); Unequal Protection: Environmental Justice and Communities of Color (Robert D. Bullard ed., 1994).

2. I use the terms "environmental racism" and "environmental injustice" interchangeably in this Article. While environmental racism is the better-known term, environmental injustice encompasses both the racial and class aspects of this phenomenon. See Laura Pulido, A Critical Review of the Methodology of Environmental Racism Research, 28 ANTIPODE 142, 149 (1996) (noting that the real challenge in environmental racism research is to "understand how racism operates in conjunction with a particular political economic system"). 
social research and analysis should "aim to evaluate the given in normative terms. Without such a critical stance, many questions about what occurs in society and why, who benefits and who is harmed, will not be asked, and social theory is liable to reaffirm and reify the given social reality." Recently, scholars have attempted to articulate the normative premises underlying the empirical conclusions. ${ }^{4}$ These articulations have helped shift the focus away from a strictly empirical assessment to a more qualitative analysis of the problem-one that ascertains the social relations and processes behind the statistics.

While grassroots stories abound in many writings on environmental justice, there is often a disjuncture between academic theories and the actual grassroots experiences of environmental injustice. This Article seeks to draw a more explicit link between the two. I will recount in detail the struggle of the Chester Residents Concerned for Quality Living (CRCQL) in Chester, Pennsylvania, and its efforts to stop the clustering of commercial waste facilities in this predominantly poor AfricanAmerican community. ${ }^{5}$ Although only one case study, Chester is not unique as a magnet for toxic waste facilities. Chester shares a similar social, political, and economic history with other areas experiencing a proliferation of unwanted toxic waste facilities-the community is a former industrial town, now populated by low-income people of color. ${ }^{6}$ Moreover, Chester residents' struggle to save their community from the proliferation of unwanted facilities is similar to many other struggles. ${ }^{7}$

3. IRIS M. Young, Justice ANd the Politics of Difference 5 (1990).

4. See, e.g., Laura Pulido, Environmentalism and Economic Justice: Two Chicano STRUGGLES IN THE SOUTHWEST (1996).

5. The Chester case study is primarily based on this author's interviews with the leader of CRCQL, Zulene Mayfield, and the lawyer representing CRCQL, Jerome Balter. In addition to these interviews, this author consulted other sources in constructing the case study: CRCQL's web site detailing their struggle and perceptions of activities surrounding the incoming waste facilities, numerous newspaper accounts detailing Chester's economic and political history, an award-winning video about the Chester struggle by a public television station in Philadelphia, see infra note 14, and a brief account of Chester's struggles by Meta Mendel Reyes, see infra note 17. I use the terms "CRCQL" and "Chester residents" interehangebly throughout this Article.

6. See, e.g., Robert D. Bullard, Environmental Justice For All, in Unequal Protection, supra note 1, at 14-15 (describing the predominantly poor, African-American Altgeld Gardens, located on the southeast side of Chicago and surrounded by fifty active or closed commercial hazardous waste landfills, 100 factories, and 103 abandoned toxic waste dumps); Sheila Foster, Ironbound Committee Against Toxic Waste: Fighting From thc Grassroots (draft Feb. 8, 1998) (on file with author) (recounting struggles of former industrial, primarily low-income immigrant neighborhood of Newark, New Jerscy which is home to an incinerator, sewage plant, and a solid waste transfer station).

7. See, e.g., Robert D. Bullard, Anatomy of Environmental Racism and the Environmental Justice Movement, in Confronting Environmental Racism, supra note 1, at 33-36 (describing common grassroots tactics, including public protest, demonstrations, petitions, lobbying local governments and state agencies, getting ordinances and resolutions passed, compiling reports and other fact-finding, community hearings, coalition-building, and litigation); Luke W. Cole, Empowerment as the Key to Environmental Protection: The Need for Environmental Poverty Law, 
I invoke the Chester case study to illustrate and explore the contours of environmental injustice in places like Chester, the efficacy of reforms in the siting process, and the political strategies and possibilities of locallybased movements for environmental justice.

Part I of this Article briefly sketches the history, causes, and effects of Chester's transformation into a haven for toxic waste facilities. It also describes Chester residents' efforts to establish its claim of environmental injustice based on the State of Pennsylvania's pattern of granting waste permits. Part II discusses the distributive paradigm in which environmental injustice is often framed. This paradigm focuses consideration of social justice on the allocation of material goods, including environmental quality, and conceives social justice and distribution as coextensive concepts. Because a purely distributive focus ignores questions of causation and agency, and obscures underlying social processes, framing environmental justice within a distributive paradigm has thwarted our understanding of the phenomenon. This Part explains that the disproportionate exposure to environmental hazards that communities such as Chester face can be traced to a set of ongoing social processes which structure the political economy of poor communities of color. The siting process, in turn, relies upon, and replicates, structural inequalities in locating new facilities.

Part III explains why grassroots struggles are important to our understanding of environmental injustice. Grassroots struggles help us understand the normative content of environmental injustice claims and provide a window into the social relations and processes that give rise to such claims. As a result, the environmental justice analysis appropriately shifts its focus to the social and structural constraints underlying the distributive outcomes. Part IV returns to the Chester case study, detailing its residents' struggle against the proliferation of toxic waste sites in their community. While their grassroots resistance began as a reaction to the impact of increasing numbers of waste facilities on the quality of life in Chester, the resistance quickly became a struggle over the legitimacy of decision-making processes, the exclusion and marginalization of disaffected citizens in those processes, and the strnctural forces that constrain individuals in communities like Chester from fully participating in decisions that fundamentally affect their lives.

Part V assesses the lessons that can be learned from the Chester struggle and the efficacy of siting process reforms in addressing the problems faced by Chester residents. The Chester case study illustrates that grassroots groups are not just fighting against distributive outcomes,

19 Ecology LQ. 619, 674-79 (1992) (recounting the strategies employed in the struggle for environmental justice in Kettleman City, California, including public protest, a letter-writing campaign, community hearings, litigation, and building on community expertise). 
but also against the institutional and social processes that produce those outcomes. The Chester struggle, along with other grassroots experiences, further suggest that distributive remedies alone will not achieve justice. Achieving environmental justice requires that siting reforms take both social structure and process seriously. This means establishing substantive criteria to prevent decision-makers from relying upon structural inequalities in the siting process and crafting more inclusive and deliberative decision-making processes in which the citizens most burdened by siting decisions have an equal opportunity to influence the outcoine of those decisions.

Part V, however, concludes that while sitmg process reforms are necessary and would address aspects of environmental injustice in Chester, these reforms should not displace the type of transformative political action currently taking place in communities such as Chester. The grassroots organizations created in the midst of struggles for environmental justice are crucial in creating an ongoing role for comınunity participation in all decisions that fundamentally affect the participants' lives. Success in these communities has meant far more than winning local struggles to defeat toxic waste facilities in already overburdened neighborhoods. When local grassroots groups are able to link their victories in the environmental realm to broader political and economic struggles, the potential exists to redefine existing power relations, to unsettle cultural assumptions about race and class, and to create new political possibilities for historically marginalized communities in local decision-making processes.

\section{I}

\section{Environmental Injustice in Chester, Pennsylvania}

Chester, Pennsylvania is an urban city of 39,000 residents. Located along the Delaware River, approximately fifteen miles southwest of Philadelphia, Chester is a small enclave of people of color within predominantly white Delaware County. While Delaware County, excluding Chester, is only $6.2 \%$ African American, Chester is 65\% African American. ${ }^{8}$ The median family income in Chester is $45 \%$ lower than in Delaware County and its $25 \%$ poverty rate is more than three times the rate in Delaware County. Unemployinent and crime are high in Chester, as is the rate of health probleins. Chester has a mortality rate $40 \%$ higher than the rest of Delaware County, as well as the state's highest child mortality rate. ${ }^{9}$

8. See Chester Residents Concerned for Quality Living v. Seif, 132 F.3d 925, 928 n.1 (3rd Cir. I997) (noting that Delaware County is $91 \%$ white and Chester is $32 \%$ white).

9. See Craig Offman, Trouble Comes to Toxic Town USA, George, Mar. 1998, at 94; Brent Staples, Life in the Toxic Zone, N.Y. TMms, Sept. 15, 1996, at A14. 
Waste facilities that once promised needed jobs have instead brought many forms of pollution. From 1986 to 1996, the Pennsylvania Department of Environmental Protection (DEP) issued seven permits for commercial waste facilities in Delaware County, five of which were in Chester. ${ }^{10}$ All of the municipal waste and sewage in Delaware County is processed in Chester, even though only $7.5 \%$ of the county population lives in Chester. ${ }^{11}$ Moreover, over $60 \%$ of the waste-processing industries in Delaware County are located in Chester. ${ }^{12}$

Living in Chester today can best be described as an assault on the senses-a toxic assault. During the summer, the stench and noise force residents to retreat into their dwellings. Recent visitors to Chester are quoted as saying that the "air is thick with acrid smells and, often, smoke. Dump trucks rumble through throughout the day," and "the first thing you notice is the smell."14

These conditions have prompted a citizen uprising against the facilities. Concerned residents began meeting privately in 1992, spurred by the noise and dust generated by trucks that brought trash to one of the largest garbage incinerators in the country-located only eighty feet from the closest homes in Chester's West End neighborhood. The residents were most irritated by the huge trucks that would rumble through their neighborhoods at all times of the day and night, disturbing their sleep and their children's recreational time, and damaging the overall character and peace of their community. Noise and vibration from the constant stream of waste trucks have caused the foundations of nearby houses to crack and property values to plummet. Residents have felt imprisoned in their own community ${ }^{\text {is }}$ Only later would they fully appreciate the damaging effects these facilities might have on the health of their community. "We are not against profit or gain, but we want to gain in our own areas," said one resident, "we want to live."16

10. See Staples, supra note 9 (noting that the five permits issued in Chester were for waste facilities which had the capacity to handle more than two million tons of waste per year; the permits issued in the rest of the county were for waste plants with the capacity to process less than one percent as much waste). A1.

11. See Mark Jaffe, Waste-Site Ruling Aids Chester Activists, Phila. Inquirer, Jan. 1, 1998, at

12. See id.

13. Michael Janofsky, Suit Says Racial Bias Led to Clustering of Solid Waste Sites, N.Y. Times, May 29, 1996, at A15.

14. Laid to Waste: A Chester Neighborhood Fights for its Furure, (DUTV television broadcast, April I996) (on file with author). "DUTV" stands for Drexel University Television. The station is an educational access channel operated by Drexel University under agreement with the City of Philadelphia, Department of Public Property. It appears as cable channel 54 in Philadelphia and can be reached at (215) 895-1054 or <http://www.duum.oce.drexed.edu/DUTV>.

15. See id. (quoting one resident describing her feeling of being "in jail").

16. Id. 


\section{A. Toxic Assault}

The recent incursion of waste treatment facilities into Chester began in the late 1980s. In 1987, the LCA Leasing Corporation, now defunct, began operating a waste transfer station in Chester that brought hundreds of truck loads of trash into Chester each day. Shortly thereafter, Abbonizio Recycling Corporation, a demolition debris recycling company arrived, creating an enormous anount of dust in the neighborhood. In 1988, despite objections from inany Chester residents, and without their input, ${ }^{17}$ the DEP granted a permit for the operation of the Westinghouse Resource Recovery Facility (Westinghouse incinerator). The Westinghouse incinerator is one of the largest in the country ${ }^{18}$ and is permitted to burn over 2,000 tons of trash per day. As well as burning $100 \%$ of Delaware County's own waste, the incinerator draws trash from three surrounding states-Delaware, New Jersey, and New York-and as far away as Ohio to feed its inassive burners. "Since 1991, when the incinerator opened, trucks ... barreled down Thurlow Street, once a quiet residential road, six days each week, often fifteen or more hours a day. ${ }^{20}$ The Westinghouse incinerator not only brought trucks and dust, but also odor and, according to residents, possibly more illness. Adults in the neighborhood experienced respiratory probleıns and their children missed more school than usual due to unexplained illness. ${ }^{21}$

The Westinghouse incinerator and Abbonizio Recycling operate in a community already surrounded by older industries such as Witco Chemicals, Scott Paper, British Petroleum, Sunoco Oil, and a twentyyear-old sewage treatment facility owned by Delaware County Regional Water Control (DELCORA). Recently, two other facilities have been issued permits to operate in Chester: Thermal Pure Systeins-an infectious inedical waste treatment facility-and Soil Remediation Systernsa contaninated soil burning plant. Chester's environmental problems today are a result of this continuing stream of toxic facilities.

The presence of these facilities may pose a grave health risk to the Chester residents. When President Clinton issued his Executive Order on

17. See Meta Mendel-Reyes, Reclaiming Democracy 155 (1995) (noting that few residents had even "heard about the single public hearing").

18. See A Review of Waste to Energy Trash Incinerators in the U.S.A., WORK ON WASTE, Jan. 1992 , at 1 .

19. The facility has also not been the best neighbor. It was fined thousands of dollars for exceeding its permitted levels of sulfur dioxide, hydrochloric acid, carbon monoxide, and other pollutants between 1992 and 1995. See Martin Indars, Westinghouse Settles Over Chester Facility; Agreement Involves State, Federal Agencies, Legal InTELligencer, May 27, 1997, at 6 (reporting the agreement between Westinghouse, the EPA, and the DEP involving a $\$ 400,000$ settlement for the clean-air emissions violations, which includes a $\$ 100,000$ fine and company sponsorship of a $\$ 100,000$ lead abatement program).

20. MENDEL-REYES, supra note 17, at 155 .

21. See id. at 153-54. 
Environmental Justice, the United States Environmental Protection Agency (EPA) chose Chester as the subject of a six-month cumulative risk assessment. This study, released in the fall of 1994, found unacceptable cancer and non-cancer risks, such as kidney and liver disease and respiratory problems, from the pollution sources in Chester. ${ }^{22}$ The EPA also concluded that (1) blood lead levels in Chester's children are unacceptably high, with more than $60 \%$ of the children's blood samples above the Center for Disease Control (CDC) recommended maximum level; ${ }^{23}$ and (2) air emissions from facilities in and around Chester account for a large component of the cancer and non-cancer risk to the citizens of Chester ${ }^{24}$ Peter Kostmayer, then head of the EPA MidAtlantic Region, said that although there was a correlation between the facilities in Chester and poor health in the community, causation was difficult to prove scientifically, due to other compounding factors. ${ }^{25}$ Nevertheless, the clustering of facilities in Chester heightens the perception that the community's poor health status is linked to the surrounding waste processing facilities.

\section{B. Tracing the Development of the Toxic Waste Industry in Chester}

At first, the facilities in Chester seemed to appear "out of nowhere. ${ }^{26}$ However, Chester's vulnerability as a wasteland for toxic disposal can be traced to its economic, social, and political history. As with many urban areas in which toxic waste facilities are located, Chester's liistory as a former industrial haven helped to shape its destiny.

22. See United States Environmental Protection Agency Region III, Environmental Risk Study for City of Chester, Pennsylvania (visited June 1995) <http://www.epa.gov/reg3hwmd/chestcr.html>.

23. This level of lead exposure is indeed a cause for great concern. Recent studies have documented the risks to children from high blood lead levels, including neurological damage leading to "lower IQ scores" as well as "deficits in psychometric intelligence scores, speech and language processing, attention, and classroom performance." Agency for Toxic Substances and Disease Registry, Neurologic Effects, U.S. Department of Health and Human Services Pubiic Health Service, Case Studies in Environmental Medicine: Lead Toxicity (visited Nov. 9, 1997) <http://atsdrl.atsdr.cdc.gov: 8080/HEC/caselead.html> (summarizing lead studies) (on file with author). A 1990 follow-up report found "a sevenfold increase in the odds of failure to graduate from high school, lower class standing, greater absenteeism, more reading disabilities, and deficits in vocabulary, fine motor skills, reaction time, and hand-eye coordination 11 years later." ld. However, there is no defimitive evidence linking the children's blood lead levels to the surrounding facilities. See Environmental Risk Study, supra note 22 (noting that it is not possible to determine the source of the lead due to lack of data).

24. See Environmental Risk Study, supra-note 22 (noting that two facilities are believed to account for half the long-term cancer risk). It should be noted that this study is still under full review and that the EPA has yet to release the full report. The above information comes from a summary of the EPA's findings released in 1995.

25. See Laid to Waste, supra note 14.

26. Russell, The Perpetrators...Russell, Rea and Zappala (visited Nov. 9, 1997) <http://www.envirolink.org/orgs/pen/crcql/mz.html (CRCQL Web Page). 
Chester's history begins in 1682 when William Penn rowed his boat ashore at a sandy stretch along the Delaware River, his first landfall in the Americas. ${ }^{27}$ Chester's location along the Delaware River "made it ideal for small-scale manufacturing." 28 By the 1770 s, Chester was a successful mill town, and it prospered as a manufacturing center until the 1940s. During this time, many southern blacks and immigrants from Poland and the Ukraine moved to Chester. ${ }^{29}$ Shortly thereafter, however, the city began a decline in prosperity that ultimately led to the Chester of today. As did many urban cities, Chester suffered from the post-war flight of its manufacturing industry overseas and the flight of middleclass whites to surrounding suburban neighborhoods. Between 1950 and 1980, 32\% of the jobs in Chester disappeared. During the same time period, the African-American population increased from $20 \%$ to $65 \% .^{30}$

Chester is now one of the most economically depressed communities in Pennsylvania. ${ }^{31}$ Predictably, social decline soon followed on the heels of the economic decline. Chester's school district is one of the worst in the state. ${ }^{32}$ Chester also has the highest crime rate in the state. ${ }^{33}$ Desperation accompanied this economic and social decline, as

27. See Michael de Courcy Hinds, Pennsylvania City Hopes It's Bouncing Back From the Bottom, N.Y. Times, Jan. 5, 1992, at A14.

28. Morgan Kelly, History of Chester (visited Nov. 9, 1997) <http:/www.envirolink.org/ orgs/pen/crcql/history.html> (CRCQL Web Page).

29. See id. (noting that Chester was also "well know [sic] for its jazz scene and it's [sic] good educational system"); see also Hinds, supra note 27 (noting that the city "thrived for 175 years, building the first iron-clad ships and becoming one of the world's busiest shipyards").

30. See Kelly, supra note 28; see also Hinds, supra note 27 (chronicling that "at an increasing pace over the last 40 years, because of high labor costs and increased competition, all but two major companies closed or moved to the South; at the same time, more southern blacks moved into Chester and many white residents moved to the suburbs"); Staples, supra note 9 (describing Chester as a "declining factory town" but "[0]nce a muscular city of 66,000 " before "Chester lost a third of its population-and more than 40,000 jobs-between the end of World War 11 and the coming of Ronald Reagan").

31. See Hinds, supra note 27 (reporting "about one of every six residents lives in public housing, one family in three receives public assistance and about one adult in three is unemployed").

32. See, e.g., Frank Reeves, City Schools Reform Plan Includes Vouchers; State Panel's Report Seeks Changes in 24 Ailing Urban Districts, Pittsburgh Post-Gazetre, Dec. 16, 1997, at C1 (noting that Chester-Upland School District meets state commission's criteria for "educationally distressed," which include high dropout rates, failure of a quarter or more of district students to meet statewide standards, high teacher absenteeism, and student attendance rates $10 \%$ or more below national norms); Master: Chaos is the Norm in Chester Schools; Students Fail Because No One Cares, Feds Say, HARrisburg Patriot, May 14, 1996, at A4 (reporting that Chester-Upland School District is on the verge of collapse, according to a federal master, due to poor student performance, high truancy, and bankruptcy).

33. See Casey Combs, Statistics Show Crime is Worse in Smaller Cities, PITtSBuRGH PosT-GazETTE, Apr. 28, 1996, at F1 (supporting analysis with 1996 FBl figures based on incidents reported by the police). 
evidenced by the city government "[e]ncourag[ing] everything and anything to come to town to provide jobs." 34

Chester did not become a toxic wasteland on its own, however. Although its history foretold its social and economic vulnerability, the situation in Chester seems partly the result of its unique political history: a corrupt Republican political machine that has long controlled many aspects of local decision-making, and some behind-the-scenes political machinations. ${ }^{35}$ Peter Kostmayer, former head of the EPA Mid-Atlantic Region, recalled hearing from a DEP official that "there were political figures and their allies that had financial investments in Chester" and supported Chester as a home to the waste industry. ${ }^{36} \mathrm{~A}$ close

34. Laid to Waste, supra note 14 (noting that the mayor of Chester and other politicians pleaded with the City of Philadelphia to transport and process its waste in Chester).

35. A summary of Chester's political history appears on a CRCQL Web site. In part, the author explains the history as follows:

Chester's political history is closely linked to its economic history. Since the turn of the century, with one exception, Chester has been ruled by a corrupt and extremely powerful political machine. The machine began in 1910 with a Swarthmore dropout named John McClure. McClure consolidated power over Chester through a campaign founded in racketeering and bootlegging.

...

McClure and the Republican party kept tight control over the city's votes by controling [sic] public funds in such a way that every government function was delivered as a personal favor. ... They were largely responsible for controlling who got jobs. . . A papcr in 1967 noted that, when asked why they voted for machine candidates, most AfricanAmericans responded that it was so they would be able to get a job. Whether or not this was true, the rumor, the fear of losing a job, was all that was necessary. The machine held the people in the palm of its hand. By delivering favors on an individual basis it kept the poor from organizing and bargaining collcctively. Effectively, it removed any power people had in the political process.

After McClure died in 1965, Jack Nacrelli, a local mobster, took control of the party. He served as mayor until 1979 when he was convicted on tax evasion, bribery and racketcering. His control was still felt from jail however, and in 1985, his secretary Willie Mae Leake became the first black mayor of Chester.

Kelly, supra note 28; see also Mark Fazlollab, Chester Sofiball Fund Probed, PhILA. INQuiRER, Jan. 4,1992 , at B3 (reporting that recent investigations have found evidence of corruption in the Chester City Council, the Redevelopment Authority, and the Resources Rccovery Authority, as well as possible malfeasance involving the City's softball fund). The New York Times reported:

Chester's Republican Party machine, one of the nation's oldest, has also been called onc of the most corrupt in recent decades by state officials. The Pennsylvania Crime Commission, an investigative agency of the State Legislature, said in a recent report last year that Chester's government had been dominated by 'a triad of criminals, corrupt politicians and rogue law-enforcement officers' since the 1960s.

Hinds, supra note 27, at A14.

Of course, political corruption is not unique to a city like Chester. Poor, disenfranchised cities are known to have a history of corruption in city government. See DAvID L. KIRP ET AL., OUR TOWN: RACE, Housing AND THE SOUl of Subureia 19, 30 (1995) (describing the political corruption that has haunted Camden, New Jersey, one of the state's poorest cities).

36. Laid to Waste, supra note 14. Kostmayer is now director of Zero Population Growth (ZPG). ZPG bills itself as "the nation's largest grassroots organization concerned with the impacts of rapid population growth and wasteful consumption." See ZPG Online (visited Apr. 9, 1998) <http://www.zpg.org/>. 
examination of the present scenario in Chester, including the issuance of waste treatment facility permits, seems to corroborate this assessment.

The most recent waste treatment facility permits issued in Chester can be traced to 1985, when Russell, Rea, and Zappala (RR\&Z), an investment banking firm froin Pittsburgh, together with Westinghouse, formed Chester Solid Waste Associates and purchased land in Chester. ${ }^{37}$ Chester Solid Waste Associates has, as its name implies, brought waste to Chester-tons of it. RR\&Z spoke with Delaware County officials about the possibility of incineration as "a solution to the county's rising waste disposal costs and the region's dwindling landfill space;" it also established the initial facilities that "brought the first glimpse of waste, trucks, and trash odors to the neighborhood." ${ }^{38}$ From there, RR\&Z's deal with Delaware County officials laid the groundwork for the issuance of a permit for construction of the massive Westinghouse incinerator. According to Chester residents, RR\&Z has retained control over every facility that has been permitted to locate in Chester, exerting direct influence over its waste processing tenants. $R R \& Z$ owns the land where the Westinghouse and Thermal Pure waste treatment facilities now sit. Moreover, most of the recently permitted facilities in Chester-LCA Leasing, Westinghouse, Thermal Pure, and the proposed Soil Remediation Systems-appear to share a corporate relationship under, the purview of RR\&Z officers. ${ }^{39}$

Not surprisingly, $R R \& Z$ has been the focus of two direct protests by outraged Chester residents. The documentary video Laid to Waste ${ }^{40}$ documented the first protest, which took place in the summer of 1995. Community activists drove to RR\&Z's Pittsburgh office and demanded a meeting. $R R \& Z$ refused to comply. $R R \& Z$ 's indifferent attitude infuses a recent press quote: "If a site is economically feasible and passes all regulatory and zoning inquiries, then it's a viable project."41 Responding to environmental racism charges, an $R R \& Z$ consultant quipped, "It's not the firm's business to feel anything about commercial transactions, all of which were legally above board and ethical."42

37. See Rick Teaff, Westinghouse, RR\&Z Team Up on Waste-to-Energy Plant, PrTTsBURGH Bus. Trmes \& J., Feb. 8, 1987, at 1; see also Don Hopey, Protestors Target Firm Helping Build Waste Disposal Sites, PitTsburgh Post-Gazette, Apr. 13, 1996, at B5.

38. Russell, Perpetrators, supra note 26; see also Teaff, supra note 37 (noting that U.S. Senator John Heinz (R-PA) inserted a provision into the 1986 tax bill that specifically retained tax benefits for the incinerator).

39. See Corporate Structure of Russell, Rea \& Zappala (visited Nov. 10, 1997) $<$ <ttp://www.envirolink.org/orgs/pen/crcql/rrz-structure.html> (CRCQL Web Page).

40. See Laid to Waste, supra note 14.

41. Hopey, supra note 37, at B5 (reporting the representative also noted that "all of the businesses were approved by the City of Chester" and that "all of the incinerators have proper permits from the State").

42. Id. (emphasis added). 
This attitude is not unique to RR\&Z's spokesman. It also underlies the inadequacies of current siting laws which allow this type of toxic proliferation in communities such as Chester. In Pennsylvania, the siting process does not consider the cumulative impact of pre-existing facilities with the proposed facility, the disproportionate location of facilities in the host community, or the demographics of the targeted community. Each permit is considered in a vacuum, requiring only that the individual facility at issue comply with applicable emission regulations and other technical requirements..$^{43}$ Moreover, once a facility is located in a host community, it is easy to expand that facility, allowing even more waste to be processed in the community. ${ }^{44}$ This has happened in Chester, where the Westinghouse incinerator continues to expand its operations and import more waste. ${ }^{45}$

The established pattern of waste treatment facilities essentially seals the community's reputation as a toxic wasteland. As Peter Kostmayer explains, "The presence of facilities molds the aesthetics and the economy. Other businesses are reluctant to locate where there are so many waste treatment plants. ${ }^{.46}$ Unfortunately, this has proven true in Chester. The new businesses that were supposed to locate near the Westinghouse incinerator have not arrived. Instead, according to resident-activist Zulene Mayfield, the only new businesses have been prostitution and drugs. ${ }^{47}$

\section{Making a Case for Environmental Injustice}

Today, the toxic assault on Chester continues. Remarkably, even with knowledge of the community's poor health and stringent opposition from local officials, in 1995 the DEP granted a permit to yet another facility, Soil Remediation Systems (SRS). SRS proposes to treat 960 tons of petroleum-contaminated soil each day at very high

43. Technical criteria can include factors such as avoiding a certain degree of proximity to wells, surface waters, residences, recreational areas, wetlands, and endangered species habitat. See Solid Waste Management Act (SWMA), $1980 \mathrm{~Pa}$. Laws 380 (codified as amended at $35 \mathrm{PA}$. Const. STAT. ANN. $\S \S 6018.101-6018.1003$ (West 1993)); Pennsylvania Department of Environmental Protection Regulations, 25 PA. CoDE $\$ 271.127$ (West Supp. 1997) (listing environmental assessment requirements for municipal waste permits).

44. See Laid to Waste, supra note 14; see also Township of Chartiers v. William H. Martin, Inc., 542 A.2d 985 ( $\mathrm{Pa}$. 1988) (lolding "natural expansion doctrine" requires municipalities to allow landfills and similar facilities to expand); 25 PA. CODE $\$ 271.126(b)(3)$ (West Supp. 1997) (exempting permit modification apphications that are not considered "major" from environmental assessment process); Michael B. Gerrard, Whose Backyard, Whose Risk: Fear and Fairness in Toxic and Nuclear Waste Siting 55 (1994).

45. See infra Section IV.F (recounting recent decision of waste authority and new owners of the incinerator to increase the volume of waste shipped to the incinerator).

46. Laid to Waste, supra note 14.

47. See Anne Linden, Pollution in the Delaware Valley: Residents Retaliate, LABYRINTH, July/Aug. 1997, at 11. 
temperatures in order to burn off contaminants so the soil can be landfilled. Subsequently, the Cherokee Environmental Group applied for a permit to process petroleum-contaminated soil by a process called "bio-remediation," in which microorganisms digest the contaminants in the soil. If allowed to operate, Cherokee will bio-remediate 900 tons of contaminated soil per day. Thus far, the residents have successfully defeated efforts by both SRS and Cherokee to build their facilities in Chester. ${ }^{48}$

The long history of environmental degradation, coupled with the relatively recent assault on Chester by the waste industry, led the community to ponder what could be done to stop waste facility permits in Chester. This question led CRCQL to file a lawsuit against the Pennsylvania DEP alleging environmental racism. In May 1996, Chester residents invoked Title VI of the Civil Rights Act, claiming that the DEP's pattern of granting permits in Delaware County is racially discriminatory. As evidence, they pointed to the clustering of waste facility permits in Chester's predominantly African-American community. The Chester lawsuit is one of only three lawsuits ever filed against a state agency in federal court alleging discrimination in the permit-granting process of waste facilities. ${ }^{49}$ The lawsuit, however, was not filed directly under Title VI. Instead, the residents claimed that the DEP violated regulations, implemented to enforce Title VI, which mandate that any jurisdiction receiving federal EPA money "shall not use criteria or methods of administering its program which have the effect of subjecting individuals to discrimination because of their race, color, national origin, or sex ...."

If successful, the Title VI lawsuit would establish legally what has already been determined empirically. ${ }^{51}$ As many studies document, commercial waste facilities are disproportionately located in poor communities of color..$^{52}$ This disparate impact and its empirical basis have

48. See infra Sections IV.D.-F.

49. The Chester suit is also the only one of the three that involves more than one facility. The other cases involved a wood-buming plant in Michigan and a waste-water treatment plant in North Carolina. See Janofsky, supra note 13, at A15.

50. 40 C.F.R. $§ 7.35$ (b) (1997) (emphasis added). There are obvious benefits to suing under the regulations, as opposed to the statute itself. The United States Supreme Court has ruled that a violation of the statute requires proof of discriminatory intent, whereas proof of discriminatory effect suffices to establish hability when the suit is brought to enforce regulations issued pursuant to the statute, rather than the statute itself. See Guardians Ass'n v. Civil Scrvice Comm'n of New York, 463 U.S. $582,591-93$ (1983).

51. Recently, the United States Court of Appeals for the Third Circuit affirmed that Chester residents have a private cause of action against the DEP under the regulations, paving the way for CRCQL's lawsuit. See Chester Residents Concerned for Quality of Life v. Seif, 132 F.3d 925 (3rd Cir. 1997).

52. See Paul Mohai \& Bunyan Bryant, Race, Poverty \& the Distribution of Environmental Hazards: Reviewing the Evidence, RACE, POVERTY \& THE ENVIRONMENT, Fall 1991/Winter 1992, 
provided substance to claims of environmental racism and environmental injustice. Highlighting the empirical results, even without legal imprimatur, has been an important political rallying point for environmental justice advocates.

But the weight placed on empirical studies as the defining characteristic or indicia of environmental injustice has also imperiled the progress of the movement. In the next Part, I argue that the conception of injustice established by these studies, and the subsequent heavy reliance upon them in framing the problem, were fraught with risks from the beginning. Although focusing on the national distributive inequities provided a starting point for inquiring about the injustice, it provided little else in the way of a substantive understanding of environmental racism. As Laura Pulido argues, the hidden assumption underlying empirical work on environmental racism is that racism is a specific thing whose effects can be neatly isolated. Limiting the concept of environmental racism to discrete and measurable discriminatory acts fosters an incomplete understanding of racism and injustice. ${ }^{53}$

II

Framing ENVIRonmental InJUSTICE: Beyond The Distributive PaRadigm

The movement for environmental justice has existed on a local grassroots level since the 1970 s. It was not until the release of two studies documenting the connection between race, class, and the distribution of environmental hazards, however, that the issue received national recognition. In 1983, a study by the United States General Accounting Office (GAO) found that three out of four landfills in the Southeastern region of the United States are located in predominantly poor and African-American communities. ${ }^{54}$ The United Church of Christ (UCC) found similar disparities on a national level in its 1987 study. 55 The UCC study measured the demographic patterns associated with commercial hazardous waste facilities ${ }^{56}$ and uncontrolled toxic waste sites. ${ }^{57}$ As for

at 3 (reviewing the numerous studies providing systematic empirical evidence regarding the burden of environmental hazards by income and race); see also infra notes 55-59 and accompanying text.

53. See Pulido, supra note 2, at 149-51. Pulido argues that recognizing racism in only measurable discriminatory acts iguores the way "racism infuses society, including culture, politics, and economic structures." Id. at 151.

54. See U.S. General accounting Office, Siting Hazardous Waste Landfills and Their Correlation with Racial Status of Surrounding Communities 3-4 (1983).

55. See Commission for Racial Justice (United Church of Christ), Toxic Wastes and Race In The UNITEd States xii (1987).

56. The UCC study defines "hazardous wastes" - as the term is used by EPA-as "by-products of industrial production which present particularly troublesome health and environmental problems." Id. The study goes on to explain that: 
the demographic characteristics of communities with commercial hazardous waste facilities, the study found that race proved to be the most significant variable in determining the location of commercial hazardous waste facilities. Communities with the greatest number of commercial hazardous waste facilities had the highest percentage of non-white residents. Its study of uncontrolled waste sites produced similar findings: Three out of every five African-American and Latino residents lived in communities with uncontrolled toxic waste sites. Furthermore, African-Americans were heavily over-represented in the populations of metropolitan areas with the largest number of such sites..$^{58}$ These studies further galvanized an already active grassroots movement, and, by highlighting the national scope of the problem, added to the already impressive array of regional studies. Since the 1980s, numerous empirical studies have continued to document the disproportionate impact of environmental hazards on poor people of color..$^{59}$

Empirical definitions of environmental racism, however, construct a particular conception of injustice and justice. Highlighting the empirical studies as the sine qua non of environmental injustice created an impression that environmental justice advocates were embracing what Iris Marion Young calls the "distributive paradigm" of justice. "What marks the distributive paradigm," according to Young, "is a tendency to conceive social justice and distributions as coextensive concepts."60

[N]ewly generated hazardous wastes must be managed in an approved "facility", which is defined by the EPA as any land structures thereon which are used for treating, storing or disposing of hazardous wastes (TSD facility). Such facilities may include landfills, surface impoundments or incinerators. A "commercial" facility is defined as any facility (public or private) which accepts hazardous wastes from a third party for a fee or other Id. remuneration.

57. The term "uncontrolled toxic waste sites" refers to closed and abandoned sites on the EPA's list of sites which pose a present and potential threat to human health and the environment. As of 1985 , the EPA inventoried approximately 200 uncontrolled toxic wastes sites across the nation. See id.

58. These areas included Memphis, Tenn. (173 sites), St. Louis, Mo. (160 sites), Houston, Tex. (152 sites), Cleveland, Ohio (106 sites), Chicago, Ill. (103 sites), and Atlanta, Ga. (91 sites). Id.

59. See, e.g., Benjamin A. Goldman \& LaUra FitTon, Toxic Wastes and Race REVISITED: AN UPDATE OF THE 1987 REPORT ON THE RACIAL AND SOCIOECONOMIC Characteristics of Communities with Hazardous Waste Stres 13-18 (1994) (finding that between 1980 and 1993, the concentration of people of color living in zip codes with commercial hazardous facilities increased from $25 \%$ to almost $31 \%$ of the average population around the facilities and that in 1993 people of color were $47 \%$ more likely than whites to live near a commereial hazardous waste facility); Vicki Been, Coming to the Nuisance or Going to the Barrios? A Longitudinal Analysis of Environmental Justice Claims, 24 Ecology L.Q. 1 (1997) (finding that the areas surrounding commercial hazardous waste treatment facilities currently are disproportionately populated by lower-income Hispanics). But see Douglas L. Anderson et al., Hazardous Waste Facilities: "Environmental Equity" Issues in Metropolitan Areas, 18 Evaluation REv. 123 (1994) (finding that the percentage of minorities living in neigliborhoods with commercial lazardous waste treatment facilities is no greater than in areas without such facilities).

60. Young, supra note 3 , at 16. 
The normative inquiry of such a paradigm is whether there is a "morally proper distribution of social benefits and burdens among society's members." cial justice on the allocation of material goods and the distribution of social positions of reward, status, and prestige. ${ }^{62}$

Focusing on a distributive notion of environmental justice carries significant epistemological risks. First, distributive notions of justice require an analysis of agency and causation in institutional and social processes that lead to the distributive outcomes reflected in the empirical research. Previous empirical studies have left these questions unresolved. The failure to explicate the forces behind the disproportionate outcomes has led skeptics to challenge the empirical and normative assumptions underlying those outcomes. Second, a monolithic focus on outcomes overshadows the way in which environmental injustice manifests itself for different social groups. In this Part, I argue that in order to move beyond the distributive paradigm, it is necessary both to understand the institutional and social processes which produce environmental hazard siting outcomes and to evaluate whether those processes are unjust. Examining the political economy of communities burdened by disproportionate environmental hazard exposures and their corresponding grassroots struggles can aid in this understanding and evaluation.

\section{A. Distribution and Process}

A purely distributive focus often obscures our consideration of the social structure and institutional context that play a role in determining the patterns of distribution. ${ }^{63}$ As Young persuasively argues, absent a deeper focus on the processes that lead to the racially disparate outcomes, the distributive paradigm implies an iucomplete social ontology. ${ }^{64}$ As such, the social justice inquiry must look beyond distributive

61. Id.

62. See id.

63. See id. at 18-24. Institutional context means something broader than the mode of production. Rather, it includes

any structures or practices, the rules and norms that guide them, and the language and symbols that mediate social interactions within them [in various institutions]. These are relevant to judgments of justice and injustice insofar as they condition people's ability to participate in determining their actions and their ability to develop and exercise their capacities.

Id. at 22. See also Evan Simpson, The Subjects of Justice, 90 ETHIcs 490, $497-98$ (1980) (critiquing the distributive paradigm for failing to bring social structure and class relations into view and evaluate them).

64. See Young, supra note 3, at 22-24 (arguing that distributive notions tend to ignore thrce primary categories of non-distributive issues: decision-making structure and procedures, division of labor, and culture); see also id. at 29 (noting that distributive measures of injustice myopically focus on a "pattern of distribution at a particular moment," instead of "the reproduction of a regular distributive pattern over time" (emphasis added)). 
patterns and instead evaluate the mechanisms and processes producing inequity. ${ }^{65}$

This is not to say that distributive patterns are irrelevant or not critical to the social justice inquiry. For many issues of social justice, the evaluation of distributive patterns over time is indeed an important starting point. In answering the question, "Why is this general pattern [being] reproduced?" we must evaluate the "matrix of rules, attitudes, interaction, and policies as a social process that produces and reproduces that pattern." ${ }^{66}$

Distribution thus should be seen not as the sine qua non of environmental racism, but instead as a crucial entry point for exploring the justice of social processes underlying distributional patterns, including environmental decision-making processes. ${ }^{67}$ As I will argue later, grassroots strnggles can provide a window into the processes that produce the distributive outcomes. ${ }^{68}$ Through an exploration and analysis of the decision-making processes and social relations in localized siting decisions, we can begin to understand both the content of specific instances of injustice and what type of policy reforms would help achieve environmental justice.

\section{B. The Problem of Causation}

A narrow focus on distribution neglects a search for causation and agency. As with most statistical research, the studies charting disproportionately distributed waste facilities simply establish correlations. As such, the empirical conclusions beg for a causal analysis of the siting process to explain existing inequities. Not surprisingly, critics have easily scrutinized the distributive paradigm of environmental injustice with causation objections. ${ }^{69}$ The insistence on establishing a linear, causal

65. See id. at 29. See also Michael WALzer, Spheres of Justice 7 (1983) (noting the need to shift our attention in questions of justice "from distrihution itself to conception and creation: the naming of goods, and the giving of meaning, and the collective making").

66. Young, supra note 3 , at 29.

67. In an important way, distributional patterns and decision-making processes are intricately intertwined. Evaluating decision-making processes often requires an evaluation of distributions. For instance, a legitimate process may depend upon an adequate distribution of various social goods, or rights, crucial to participation in that process. See RoBerT A. DAHL, DEMOCRACY AND ITS CRITICS 163-I75 (1989) (arguing that certain rights, goods and interests are integral to a legitimate democratic process). In turn, decision-making processes determine the distribution of other rights and social goods. See id. For instance, some social groups approach environmental decision-making processes with fewer social goods, e.g., time, education, imformation and specialized knowledge, than more privileged groups. Not surprisingly, these same groups remain disadvantaged in the distribution of social goods by those processes. See infra Part V (describing the connection between distributional inequities and environmental decision-making processes in places such as Chester).

68. See infra Part III.

69. See, e.g., Vicki Been, What's Fairness Got to Do with It? Environmental Justice and the Siting of Locally Undesirable Land Uses, 78 CORNELL L. REv. 1001, 1016 (1993) (arguing that one "causation objection" to the empirical evidence is that it "does not establish that siting choices caused 
connection between undesirable outcomes and a responsible, identifiable agent, such as the siting process, permeates our legal and social understandings of racism and injustice. ${ }^{70}$ However, the prevailing demand for proof of causation, particularly underlying civil rights theory and doctrine, is premised on a static, atomistic conception of agency ${ }^{71}$ which disaggregates individuals and institutions from their social context. ${ }^{72}$

Understanding environmental injustice requires a broader causal analysis. Specifically, it requires a conceptual framework that (1) retains a structural view of economic and social forces as they influence discriminatory outcomes; and (2) isolates the dynamics within environmental decision-making processes that further contribute to such outcomes. Yet, understanding environmental injustice requires that we must also evaluate these social processes. Evaluating processes

the disproportionate impact ... on people of color and the poor"); Lynn E. Blais, Environmental Racism Reconsidered, 75 N.C. L. REv. 75, 90 (1996) (noting that "while many environmental racism scholars challenge the equity of the existing distribution based on perceived process failures, none have advanced a coherent theory of these failures").

70. See Sheila Foster, Race(ial) Matters: The Quest for Environmental Justice, 20 Ecology L.Q. 721, 731-35 (1994).

71. For instance, this understanding is reflected in recent amendinents to Title VII of the Civil Rights Act of 1964, prohibiting employment discrimination. The Civil Rights Act of 1991, Pub. L. No. 102-166, 105 Stat. 1071 (codiffed as amended at 42 U.S.C. $\$ 2000 \mathrm{e}-2000 \mathrm{e}-16$ ) (West 1994), provides that the disparate impact of an employer's actions on a particular group gives rise to hability only if plaintiff can (1) identify with particularity the objectionable employment practice and (2) demonstrate that the employment practice caused the disparate impact. See 42 U.S.C. $\S 2000$-2(k) (West 1994); See also Wards Cove Packing Co. v. Antonio, 490 U.S. 642, 656-67 (1989) (requiring plaintiffs to identify the specific employment practice alleged to cause the disparate impact and to prove causation in order to make out a prima facie case of disparate inpact liability); see also Alan Freeman, Antidiscrimination Law: The View from 1989, 64 TuL. L. Rev. 1407, 1412-13 (1990) (describing the victim/perpetrator approach, whereby civil rights laws have bcen interpreted such that violations occur only where "actions of identifiable perpetrators... have purposefully and intentionally caused harm to identifiable victims").

72. A prime example of the type of causation analysis typical in contemporary civil rights cases is the Supreme Court's holding in Freeman v. Pitts, 503 U.S. 467 (1992). In Freeman, the Court terminated a desegregation order imposed on a school district, despite continued racial segregation in public schools, holding that current school segregation caused by segregative housing patterns was not enough to justify continued court supervision of the district's duty to integrate. See id. at 495 . In particular, the Court reasoned that "the population changes which occurred in [the] County were not caused by the policies of the school district, but rather by independent factors ... consistent with the mobility that is a distinct characteristic of our society." Id. at 494. In fact, "[t] he effect of changing residential patterns on the racial composition of schools, though not always fortunate, is somewhat predictable." Id. at 495 (citing a study demonstrating a high correlation between residential and school segregation). As such, the Court concluded, even though housing segregation can be traced to discriminatory attitudes, and leads to school segregation, "[w] here resegregation is a product not of state action but of private choices," it is beyond the "authority and ... practical ability of the federal courts to try to counteract these kinds of continuous and massive demographic shifts." Id. Any attempt to intervene in these demographic patterns and private choices "would require ongoing and neverending supervision by the courts of school districts." Id. Given the Court's narrow view of causation, comununity activists and scholars interested in environmental justice must not rely on legal definitions of causation. Moreover, given the Court's himited view of institutional responsibility, those pursuing social justice must realize they can no longer expect courts to take the lead in effecting change. 
underlying distributive outcomes requires both empirical and normative assessments of those processes. ${ }^{73}$ Case studies like Chester embody a more multivalent understanding of causation, and can help in evaluating the social processes underlying distributive outcomes.

\section{The "Chicken or Egg" Question}

One of the most important causation objections to the empirical research, upon which the distributive paradigm rests, asks the question: "Which came first, the environmental hazard or the racial and/or the class makeup of the neighborhood?"74 The suspicion underlying this objection is that researchers have failed to isolate the particular processes responsible for producing the racially disparate outcomes. Specifically, commentators note that studies charting the racially disparate outcomes fail to compare the demographics of the neighborhoods at the time the facilities were sited with demographics at the time measured by the studies. This failure "leaves open the possibility that [the facilities] were not disparately sited in poor and minority neighborhoods," but that "market dynamics" led people of color and the poor to "come to the nuisance," that is, to move to areas surrounding waste facilities because those neighborhoods offered the cheapest available housing. ${ }^{75}$ If this is the case, then such post-siting "market dynamics" would be responsible for the distributive outcomes, not environmental decisionmaking processes.

Vicki Been, for instance, describes two factors which influence the poor to move to neighborhoods which may be otherwise undesirable to most people. The first factor is the cost of housing; the second is the characteristics of a neighborhood. ${ }^{76}$ Noting that the housing market in the United States is "extrennely dynainic," Been explains that regardless of whether Locally Undesirable Land Uses (LULUs) were sited fairly originally, it could well be that neighborhoods surrounding LULUs became poorer and thus home to a greater percentage of people of color in the years following the siting. A LULU "may cause those who can

73. Young rejects the division between empirical and normative social theory, arguing that: no normative theory meant to evaluate existing societies can avoid an empirical inquiry, and no empirical investigation of social structures and relations can avoid normative judgments. Inquiry about social justice must consider the context and cause of actual distributions in order to make normative judgments about institutional rules and relations.

Young, supra note 3, at 29. See also Walzer, supra note 65, at 9 ("Social meanings are historical in character; and so distributions, and just and unjust distributions, change over time.").

74. See Vicki Been, Locally Undesirable Land Uses in Minority Neighborhoods: Disproportionate Siting or Market Dynamics?, 103 YALE L.J. 1383, 1384-91 (1994); see also Thomas Lambert \& Christopher Boemer, Environmental Inequity: Economic Causes, Economic Solutions, 14 YALE J. ON Reg. 195 (1997).

75. Been, supra note 74, at 1389; see also Lambert \& Boemer, supra note 74, at 200-202.

76. See id., at 1388-89. 
afford to move to become dissatisfied and leave the neighborhood," or it "may decrease the value of the neighborhood's property, making the housing more available to lower income households and less attractive to higher income households." 7

Since the market is the realm of private transactions, where goods, services, and information are exchanged in accordance with the ability to pay, it predictably allocates to the poor the least desirable neighborhoods-imcluding those containing a hazardous waste facility. ${ }^{78}$ As Been explains, "[a]s long as the market allows the existing distribution of wealth to allocate goods and services, it would be surprising indeed if, over the long run, LULUs did not impose a disproportionate burden upon the poor." It is the inarket, she concludes, that may ultimately lead the poor to "come to the nuisance," to move to neighborhoods that host LULUs. ${ }^{80}$

Market theories, however, are notoriously incomplete. As others have argued persuasively, markets are social institutions shaped by various levels of state and private control. ${ }^{81}$ The historical and present reality of race discrimination inevitably, and not surprisingly, affects individual preferences and mobility in the housing arena. ${ }^{82}$ Been is careful not to overlook its influence. As she notes, the existence of a LULU, in addition to attracting lower incoine residents and deterring higher income households, ensures that "[t]he neighborhood also is likely to become home to more people of color." ${ }^{\text {"S3 }}$ She acknowledges that the impact of "[r]acial discrimination in the sale and rental of housing relegates people of color (especially African-Americans) to the least desirable neighborhoods, regardless of their incoine level."84 Moreover, even after a neighborhood becomes predominantly composed of people of color, Been recognizes that "racial discrimination in the promulgation and enforceinent of zoning and environmental protection laws, the provision

77. Id. (footnotes omitted). Notably, and ironically, a later empirical study performed by Been failed to provide support for her "market dynamics" theory. See Been, supra note 59, at 27-29, 34. But see infra note 89.

78. See Blais, supra note 69 , at 93 (explaining that "[t]he market allocates according to ability to pay; the more money one has, the more of any particular good-including a clean environmentone can afford to purchase").

79. Been, supra note 74, at 1390 (emphasis added).

80. See id.; see also Lambert \& Boemer, supra note 74, at 202.

81. See, e.g., Cass R. Sunstein, Free Markets and Social Justice (1997); Blais, supra note 69, at 141; Cass R. Sunstein, Preferences and Politics, 20 PHIL. \& PuB. AFF. 3, 10 ("[P]references are shifting and endogenous rather than exogenous, and as a result are a function of current information consumption patterns, legal rules and general social pattems.").

82. See Richard T. Ford, The Boundaries of Race: Political Geography in Legal Analysis, 107 HARV. L REv. 1841 (1994) (arguing that housing and spacial segregation is not "natural," but rather constructed through various public and private actions, including racial discrimination).

83. Been, supra note 74 , at 1389.

84. Id. 
of municipal services, and the lending practices of banks, may cause neighborhood quality to decline further" and that "[the] additional decline ... will induce those who can leave the neighborhood-the least poor and those least subject to discrimination-to do so." 85 She concludes that, "[a]s long as the market discriminates on the basis of race, it would be remarkable if LULUs did not eventually impose a disproportionate burden upon people of color." 86

Been finds this scrutiny of the distributive paradigm of environmental justice fatal. Critiquing the studies which establish the race and class correlations, she concludes that "[b]y failing to address how LULUs have affected the demographics of their host communities, the current research has ignored the possibility that the correlation between the location of LULUs and the socio-economic characteristics of neighborhoods may be a function of aspects of our free market system ...." 87 The implications of this failure, she believes, go right to the heart of environmental justice research and its remedy. As she explains, "Both the justice of the distribution of LULUs and the remedy

85. Id. (footnotes omitted). See also Douglass S. Massey \& NANCY A. DEnton, AMERICAN Apartheid: Segregation and the Making of the Underclass 114 (1993). Massey and Denton found that "race is the dominant organizing principle" for "housing and residential patterns." Id. They conclude that:

[t]hrough a series of exclusionary tactics, realtors limit the likelihood of black entry into white neighborhoods and channel black demand for housing into areas that are within or near existing ghettos. White prejudice is such that when black entry into a neighborhood is achieved, that area becomes unattractive to further white settlement and whites begin departing at an accelerated pace. This segmentation of black and white housing demand is encouraged by pervasive discrimination in the allocation of mortgages and home improvement loans, which systematically channel money away from integrated areas.

Id. According to one study, among neighborhoods located within five miles of an established black neighborhood, white population loss is extremely likely, and becomes virtually certain as the percentage of blacks increase. This pattern holds true for suburbs as well as central cities. The probability that a central city tract located within five miles of a black neighborhood would lose white residents was .85 when its black percentage was $0 \%-5 \%$ black; and it rose to .92 when the black percentage reached $30 \%-40 \%$. See id. at 80 .

86. Been, supra note 74, at 1389 (emphasis added).

87. Id. I am troubled by Been's use of market rhetoric, and in particular the language of the "free market," to describe housing dynamics underlying distributive outcomes. Even while acknowledging that racial prejudice infects decision-making processes in the housing market, her rhetoric has the effect of expanding the domain of the "free market" to include discriminatory practices. This would not be so problematic if free market analysis were not so connected to purely economic relationships, which are presumed to be "natural." For instance, legal realists have referred to the mystification of economic relationships as "natural," and as a function of legal doctrine and legal reasoning. See e.g., Robert Hale, Coercion and Distribution in a Supposedly NonCoercive State, 38 PoL. Scr. Q. 470 (1923). Hence, when Been opines that the free market or market dynamics cause a particular distribution, it would be easy to attach a normative meaning-that such dynamics are natural-to her essentially empirical analysis of post-siting housing dynamics. Although I suspect that she does not intend such normative implications, see note 88 infra, I wish the terms used to describe her empirical analysis did not carry such implications. 
for any injustice may differ if market dynamics play a significant role in the distribution."

\section{Empirical versus Normative Causation}

Undoubtedly the "dynamics" of the housing market-broadly construed to include discriminatory practices-can theoretically account for some of the racially disparate environmental hazard distribution patterns. ${ }^{89}$ As others have pointed out, there might be a number of developmental patterns, given the combination of poverty and racially discriminatory practices, that would result in poor people of color either moving to or becoming trapped in neighborhoods with a disproportionate number of hazardous sources. ${ }^{90}$ Determining the various factors that

88. Been, supra, note 74 , at 1390 . For instance, if the "fairness of the distribution becomes a question about the fairness of our market economy," there will be those who respond that the market economy "is, overall, fairer than alternative schemes, and that the costs of regulating the market to reduce the disproportionate burden outweigh the benefits of doing so," or "that those moving to a host neighborhood are compensated through the market for the disproportionate burden they bear by lower housing costs, and therefore that the situation is just." Id. at 1391-92. On the other hand, even if decision-makers agreed that it is unfair to allow post-siting market dynamics to create the disproportionate environmental risk for the poor and/or people of color, "the remedy for that injustice would have to be much more fundamental than the remedy for unjust siting decisions." Id. at 1392. An effective remedy would require, instead, more fundamental reforms, such as:

strieter enforcement of laws against housing discrimination, more serious efforts to achieve residential integration, changes in the processes of siting low and moderate income housing, changes in programs designed to aid the poor in securing decent housing, greater regulatory protection for those neighborhoods that are chosen to host LULUs, and changes in production and consumption processes to reduce the number of LULUs needed.

Id.

89. Notably, there is inconclusive empirical support to date for the "market dynamics" explanation for racial or economic disparities in the distribution of hazardous waste facilities. See, e.g., Been, supra note 59, at 8, 33 (finding that the areas surrounding commereial hazardous waste treatment facilities cumently are populated disproportionately by lower-income Hispanics; and finding that there is no evidence to support her "market dynamics theory"-that these communities became poorer or increased in minority population after the waste facilities were sited); Been, supra note 74, at 1398-1400 (finding that the Southeastern waste sites studied by the U.S. General Accounting Office in 1983 were all in communities that originally had both high levels of poverty and predominantly African-Ameriean populations; and finding that these communities did not become poorer nor did the percentage of African-Americans in the communities increase in the period after the faeility was sited). But see id. at 1400-06 (finding that ten Houston waste sites studied in 1983 by Professor Robert Bullard were originally sited in disproportionately African-American communities, but they did not originally have disproportionately lower incomes; however, finding that the percentages of African-Americans rose and incomes fell after the solid waste facilities were sited); Lambert \& Boemer, supra note 74, at 206-07 (finding that "[b]etween 1970 and 1990, concentrations of poor and minority individuals increased disproportionately around the St. Louis area's CERCLA [Comprehensive Environmental Response, Compensation, and Liability Aet] sites, TSDFs [treatment, storage, and disposal facilities], and nonhazardous landfills and ineinerators"); Douglas Anderson et al., supra note 59, at 135 (finding evidence of economic decline in communities with commercial hazardous waste facilities, but no evidence of white fiight from those neighborhoods after the siting of such facilities).

90. For instance, communities where poor minorities now live may have originally been the homes of whites who "worked in the facilities that generate toxic emissions." Regina Austin \& 
contribute to the distributive outcomes is indeed an important epistemological question.

The chicken or egg quandary posed by commentators does not, however, answer the more fundamental inquiry posed by environmental justice research. The question underlying environmental justice research is normative. It asks, "What do we mean when we call an outcome racist or evidence of injustice?"91 The chicken or egg inquiry posed by commentators such as Been is empirical. It asks, "Which came first: the waste facilities or the poor people of color?" Answering the second question does not necessarily answer the first, that is, the normative claim embedded in environmental justice research is not answered simply by a descriptive analysis of forces underlying a particular distributional pattern..$^{93}$ The post-siting market dynamics analysis is certainly useful in determining whether it is more descriptively correct to attribute environmental disparities to the siting process or other forces outside of that process. However, even if one could establish that market dynamics, and not the siting process, produce racially disparate outcomes, this would not tell us whether such market forces are just or fair. Uncovering the patterns and processes underlying the distributive outcomes is an important first step; a normative evaluation of these outcomes is the next crucial step.

Michael Schill, Black, Brown, Red \& Poisoned, in UNEQUAL PROTECTION, supra note 1, at 53. In those communities, the housing and industry may have "sprang up roughly simultaneously" and whites may have "vacated the housing (but not necessarily the jobs) for better shelter as their socioeconomic status improved." Id. at 54. In turn, poorer Latinos and African-Americans "who enjoy much Iess residential mobility" may have taken their place. Id. In another pattem, housing for AfricanAmericans and Latinos may have been built in the vicinity of existing industrial operations because "the land was cheap and the people were poor." Id. In still another pattern, "sources of toxic pollution may have been placed in existing minority communities." Id. at 54.

91. See Foster, supra note 70, at 731.

92. Been's project is admittedly empirical. She wants only to "address the gaps in the research" establishing racially disproportionate exposure to environmental hazards. Doing so, she hopes, will demonstrate "why an empirical understanding of the role of market dynamics play in the distribution is necessary" to reach normative conclusions "about the fainess of the existing distribution of LULUs and to fashion an effeetive remedy for any unfairness in that distribution." Been, supra note $\mathbf{7 4}$, at 1386 . She does not, however, explicitly reach any normative conclusions about whether these market dynamics render the distributional outcomes racist or suggest evidence of injustice. See also Lambert and Boerner, supra note 74, at 206, 212 (finding that their analysis supports the theory that "minority and poor [individuals] voluntarily move into areas surrounding industrial and waste sites" in St. Louis, but cautioning that "the conclusions drawn from this study may provide an incomplete picture of environmental justice," and "other forms of racial discrimination may have been a factor influencing the subsequent migration of these residents to communities hosting polluting facilities.").

93. I am indebted to Angela Harris for this insight. Economists and others have noted the limitations of economic analysis and the need to make a distinction between descriptive and normative analysis. See generally RICHARD A. POSNER, Overcoming LAW 1-29 (1995) (arguing that empirical reality should inform normative theories and expressing the limitations of economic analysis to provide normative answers); Frank I. Michelman, Norms and Normativity in the Economic Theory of Law, 62 MinN. L. REv. 1015, 1040 (1978) (noting how economic analysis "can carelessly slip from an approximate empirical 'Is' to a definite idcal 'Must or Ought to Be"'). 
As I have argued elsewhere, if existing racially discriminatory processes in the housing market, for instance, contribute to the distribution of environmental hazards, then it is entirely appropriate to call such outcomes unjust, and even racist. ${ }^{94}$ Many toxic waste sites are located in racially segregated, and impoverished communities, such as Chester. ${ }^{95}$ Racially discrimmatory processes, as many have noted, play a determinative role in constructing segregated and impoverished neighborhoods. ${ }^{96}$ The combination of white flight and limited residential choices, likely due to a combination of poverty and housing discrimination, along with falling property values, has left poor people of color essentially trapped in environmentally subordinate neighborhoods. So long as the distribution of environmental hazards are produced, even in part, by a discriminatory social structure, environmental injustice exists. ${ }^{97}$

\section{Evaluating Current Siting Processes}

The preceding empirical and normative assessment of post-siting market dynamics is still an incomplete causal account of environmental injustice in communities such as Chester. Market dynamics may explain how Chester became a predominantly poor community of color after the influx of industry and its manufacturing base. Post-siting market dynamics does not explain the current siting pattern in Chester.

94. Foster, supra note 70, at 735-38; see also Gerald Torres, Introduction: Understanding Environmental Racism, 63 U. CoLo. L. REv, 839, 839 (1992) (explaining that "the term racism draws its contemporary moral strength by being clearly identified with the history of the structural oppression of African-Americans and other people of color in this society").

95. See Been, supra note 59, at 30 (noting that a comparison of the means of demographic variables for 544 tracts hosting active commercial waste sites in 1994 reveals that "[h]ost tracts have a much less educated population[,] ... higher levels of unemployment, lower levels of employment in the professional occupations, higher levels of employment in manufacturing occupations," and are disproportionately Hispanic); see also GoLDMAN \& FITTON, supra note 59, at $i$ (finding that, in 1993, people of color were $47 \%$ more likely than whites to live near a commereial hazardous waste facility).

96. See Been, supra note 88; MASSEY \& Denton, supra note 85; Ford, supra note 82.

97. Presumably, commentators like Been would agree with this normative analysis. Even though Been's overall analysis seems to be free of normative judgment, instead merely raising empirical problems with the research, at one point her analysis does reveal that "[i]f the market forces at issue are based upon discrimination, i.e., if host neighborhoods became predominantly minority after the LULU was sited because racial discrimination in the housing market relegated people of color to those neighborhoods, siting practices might have to change to account for persistent discrimination in the housing market." Been, supra note 74, at 1391, n.30 (comparing United States v. Yonkers Bd. of Educ., 624 F. Supp. 1276, 1531-37 (S.D.N.Y. 1985). But see Freeman v. Pitts, 503 U.S. 467 (1992) (rejecting the argument that educational decision-making processes must change to account for housing market discrimination partly responsible for reproducing racially segregated schools).

98. See Cerrell Associates, Inc., Political Difficulties Facing Waste-to-Energy Conversion Plant Siting 65 (1984) (consulting report prepared for Califomia Waste Management Board) ("[T] he people most hkely to express opposition ... to a project [are] residents in the vicinity, liberal, and higher educated persons"); see also Lois Marie Gibbs \& Brian Lipsett, The Siting Game: A NIMBY Primer, 8 F. APPLIED Res. \& PUB. POL'Y 36, 37 (1993) (describing siting efforts in North Carolina that target pohitically weak communities). 
Examining the structured inequalities resulting from market dynamics in communities such as Chester does, however, help one understand and evaluate current siting processes within their social context.

Although the siting process does not produce the structured inequalities in communities such as Chester, it is heavily dependent upon them. Conventional industry wisdom counsels private companies to target sites that are in neighborhoods "least likely to express opposition"-poorly educated and lower socioeconomic neighborhoods with little if any commercial activity. ${ }^{98}$ Communities such as Chester possess many of these characteristics. This is due in part to historical zoning practices and their segregative effects. ${ }^{99}$ This racialization of space "reaches to the societal processes in which people participate and to the structures and institutions that people produce." ${ }^{" 100}$ Residential location, for instance, is seen as an indication of the attitudes, values, and behavioral inclinations of the types of people who are assumed to live there. ${ }^{101}$ Moreover, segregation has intense political and economic consequences, particularly for poor African Americans and Latinos living in innercities. ${ }^{102}$ Segregated communities are not only geographically isolated,

99. For instance, Yale Rabin describes one type of zoning practice-expulsive zoning-as contributing to the maintenance of racially segregative communities:

The record, while admittedly fragmentary, indicates that in the years following the [Supreme] Court's rejection of racial zoning in 1917 and continuing through the thirties, and perhaps much later, a number of cities-mainly, but not exclusively, in the South-zoned some low-income residential areas occupied mainly, but not exclusively, by blacks for industrial or commercial use. These practices were sonnetimes carried out even in neighborhoods of single-family detached homes, thus undermining the quality of the very types of neighborhood which zoning ostensibly was intended to protect. To the extent that these practices were effective-that is, to the extent that residential uses were replaced by industrial or commercial uses, residents were displaced. Therefore, the term expulsive zoning. Because it appears that such areas were mainly black, and because whites who may have been similarly displaced were not subject to racially determined limitations in sceking alternative honsing, the adverse impacts of expulsive zoning on blacks were far more severe and included, in addition to accelerated blight, increases in overcrowding and racial segregation.

Yale Rabin, Expulsive Zoning: The Inequitable Legacy of Euclid, in ZONING AND THE AMERICAN Dream: Promises Still to KeEP 101-02 (Charles M. Haar \& Jerold S. Kayden eds., 1989) (emphasis in original); see also John C. Dubin, From Junkyards to Gentrification: Explicating a Right to Protective Zoning in Low-Income Communities of Color, 77 MrNN. L. Rev. 739 (1993) (discussing historical zoning practices and their present-day segregative effects).

100. John O. Calınore, Racialized Space and the Culture of Segregation: "Hewing a Stone of Hope from a Mountain of Despair," 143 U. PA. L. REv. 1233, 1235 (1995); see also Ford, supra note 82 , at 1852 ("[A]lthough political space scems to be the inert context in which individuals make rational choices, it is in fact a controlling structure in which scemingly innocuous actions lead to racially detrimental consequences.").

101. See Susan J. Smith, Residential Segregation and the Politics of Racialization, in RAC1SM, THE Ciry and the State 128, 133 (Malcolm Cross \& Michael Keith eds., 1993).

102. Although Massey and Denton describe poor blacks as "hyper segregated"-unlikely to have any direct contact with the larger society unless they work outside of their neighborhoodsother groups also experienced varying degrees of segregation. See MASSEY \& DENTON, supra note 85, at 74, 113-14 (comparing the segregation of Caribbean Latinos with blacks and concluding that the average level of segregation increases steadily as one moves from being identified as white 
but socially and culturally isolated. This isolation, in turn, leads to economic and political marginalization. ${ }^{103}$ Accordingly, the political process rarely takes the concerns of such communities seriously, and decision-makers often ignore them altogether. ${ }^{104}$

The hazardous waste siting process begins with the private sector choosing an appropriate site for the location of a proposed facility. Because the proposed location of a hazardous waste facility near, particularly, a white, upper-socioeconomic neighborhood often engenders strong public opposition, there is a limited supply of land on which to site such facilities. ${ }^{105}$ Inevitably, the siting process focuses on industrial or rural communities, many of which, like Chester, have predominantly minority populations. ${ }^{106}$ These areas are attractive to industries seeking

Hispanics, to mixed-race Hispanics, to black Hispanics-the latter have an "index" of segregation comparable to that of African-Americans).

103. See William Julius Wilson, When Work Disappears: The World of the NeW URBAN POOR 51-86 (1996) (finding that social isolation deprives inner-city residents not only of conventional role models but also of the social resources provided by mainstream social networks that facilitate social and economic advancement in a modern industrial society).

104. As one commentator has remarked:

The organization of space is often critical in determining what is politically possible in the U.S. because so many aspects of American politics and policy are tied to geographical boundaries. The migration of southem blacks to northem cities from the $1920 \mathrm{~s}$ on, but especially during the 1950 s with the mechanization of southern agriculture, left blacks concentrated within central cities at a time when many whites were leaving the city for newly constructed, federally subsidized suburbs. This geographic separation of blacks has important political consequenccs: it transforms the problems of living in cities into "black" problems, making it easier for politicians to solve urban problems at the expense of poor black residents. They, in fact, become the problem as cities become polarized between the rich and the poor. This geo-political separation exacerbates the disconnection of the black poor from whites, as the fate of the city becomes not a shared interest, but part of a battle over low resources will be distributed across political boundaries.

Margaret Weir, From Equal Opportunity to "The New Social Contract": Race and the Politics of the American Underclass, in RACISM, THE CTTY AND THE STATE, supra note 101, at 104; see also WILsoN, supra note 103 , at $185-86$. Wilson notes:

The growing suburbanization of the popnlation influences the extent to which national politicians will support increased federal aid to large cities and the poor.... [W] can associate the sharp drop in federal support for basic urban programs since 1980 with the declining political influence of cities and the rising influence of electoral coalitions in the Id. suburbs.

105. Industry considers public opposition, and often direct protest, to be the "greatest single obstacle to the successful siting of' hazardous facilities, with middle- and upper-level socioeconomic groups possessing greater resources to effectuate their opposition. Cerrell Associates, supra note 98, at 64; see also Gibbs \& Lipsett, supra note 98 , at 43 (counseling that "middle and higher socioeconomic strata neighborhoods should not fall within the one-mile and five-mile radius of the proposed site"); Richard J. Lazarus, Pursuing "Environmental Justice": The Distributional Effects of Environmental Protection, 87 Nw. U. L. REv. 787, 806 (1993) (noting that few proposals survive public review that often accompanies the announcement of the rccommended siting of a hazardous waste facility).

106. Robert Bullard, Environmental Blackmail in Minority Communities, in RACE AND THE INCIDENCE OF ENviRoNmental Hazards 85-86, 90-91 (Bunyan Bryant \& Paul Mohai eds., 1992) (noting that when the middle- and upper-income neighborhoods defeat proposed hazardous waste sites, the siting effort shifts toward more historically powerless neighborhoods, such as poor minority 
to reduce the cost of doing business because land values are lower in heavily industrial and rural communities. ${ }^{107}$ Furthermore, these communities are presumed to pose little threat of political resistance due to their subordinate socioeconomic, and often racial, status. ${ }^{108}$

The state both mediates and legitimizes the dependence of private decision-makers on structural inequalities in choosing facility sites. Even though private decision-makers must seek permits from state agencies, there are often no formal criteria which take into account the siting processes' reliance on structural inequalities; ${ }^{109}$ too often state agencies passively acquiesce to industry siting decisions. ${ }^{110}$ Aside from

neighborhoods). Certain neighborhoods have traditionally provided the location for industrial land uses. Zoning practices in the early part of the century routinely zoned many African-American communities as industrial and white areas as residential. See Rabin, supra note 99, at 101-02 (finding that expulsive zoning practices have been relatively commonplace in black residential areas, permitting the intrusion of disruptive compatible uses into those areas and generally undermining the character, quality, and stability of black residential areas). "Such patterns, once established, are difficulty to alter. LULUs result in depressed residential property values which, in turn, reduce the municipal tax base and discourage other upscale development which would help boost property values." Jason Wilson, Environmental Inequity: Which Came First, Poverty or Pollution?, N.J. REP., Mar./Apr. 1997, at 40.

Moreover, in certain geographic regions, the rural nature of a community becomes a surrogate for poor minority communities. For example, Conner Bailey and Charles E. Faupel, in a discussion of the nation's largest hazardous waste landfill in Emelle, Alabama, describe why it may have been chosen as a site:

A sparse population often is a good indicator of poverty. In the context of Alabama, and the South generally, the population of poor and sparsely populated rural counties is likely to be mostly black. It follows that criteria for siting hazardous waste facilities which include density of population will have the effect of targeting rural black communities that lave high rates of poverty.... Communities which fit this description are [also] likely to be politically marginal at the state and federal levels.

Conner Bailey \& Charles E. Faupel, Environmentalism and Civil Rights in Sumter County, Alabama, in RACR AND THE INCIDENCE OF ENvIRONMENTAL HAZARDS, supra; at 150; cf. GerRaRd, supra note 44 , at 90 (noting that "[m]ost of the anecdotes and much of the data concerning discriminatory siting come from the southeastern United States ... [and that] is a region where, for obvious historical reasons, rural areas have large black populations; in the northeast, where the rural areas are mostly white, most proposed sites have been in white areas").

107. See GERRARD, supra note 44, at 47; Mohai \& Bryant, supra note 52, at 24.

108. See Cerrell Assoctates, supra note 97, at 5 (noting report designed to assist in selecting a site that offers the least amount of "political resistance"); id. at 65 (noting that "older, conservative, and lower socioeconomic neighborlıods" are least likely to resist sitings).

109. See infra note 113 .

110. See supra note 43 and accompanying text. States have taken vastly different approaches to the siting of these facilities, but most of the approaches cast the state in a passive role in the siting process:

Siting statutes vary from the extremely passive to the strongly active. The passive approacl leaves it to the private sector to initiate proposals for new facilities, and local governments retain significant power to approve or deny proposals. In the active approach, the state develops a state-wide management plan, initiates the siting process by identifying locations suitable for a facility and actively soliciting private sector participation, and preempts all local authority .... Some states went so far as to mandate that a facility must be sited; a few were willing to own and operate a state facility. Overall, surveys indicate that strong initiative is "a minority approach to siting" and that most states opted for the more passive end of the spectrum. "Generally, states appear to prefer the role of guardian to the siting 
technical siting criteria and lax public notice requirements, ${ }^{111}$ the permitting decision is almost entirely in the discretion of state administrative agencies. ${ }^{112}$ Unfortunately, state agencies determine a proposed facility's impact on the community in a vacuum, rarely looking beyond the geological and environmental characteristics of the proposed site. ${ }^{113}$ Rarely is there any formal assessment of the demographics, health problems, quality of life and infrastructure of the surrounding community, or the synergistic environmental or health effects of other facilities in the area. ${ }^{14}$ When the siting process is neutral toward these structural inequalities it, in effect, perpetuates the injustice of the current social structure. ${ }^{115}$ The end result of environmental decision-making processes, particularly in communities such as Chester, is not that people "come to the hazard," but rather that "the hazard comes to them." 116

\section{The Many Faces of Injustice}

An overwhelming focus on unequal distribution as injustice also implies that redistribution alone could achieve environmental justice. Environmental justice is often regarded as the equitable distribution of

process while allowing the private sector to set the pace and initiate specific siting proposals."

ANDREW Szasz, EcoPopulism: TOXic WASTE AND THE MOVEMENT FOR ENVIRONMENTAL JUSTICE 183 n.26 (1994) (citations omitted) (emphasis in original).

111. For instance, in Chester, the site for the Westinghouse incinerator was chosen without any input from residents opposed to the siting, few of whom even heard about the single public hearing. See also infra Part IV B (discussing public comment and notice requirements in Pennsylvania).

112. See Gerald Torres, Environmental Burdens and Democratic Justice, 21 FORDHAM URB. L.J. $431,452-53$ (1994).

113. See A. Dan Tarlock, State yersus Local Control of Hazardous Waste Facility Siting: Who Decides in Whose Backyard?, in Resolving Locational Conflict 137, 150-51 (Robert W. Lake ed., 1987). However, some states do mandate that agencies consider so-called "nontechnical" criteria, such as "objections submitted by the public" (Michigan) or "community perceptions and other ... costs" (Kentucky). Id. at 150. The question remains whether these so-called "soft" criteria are given the same, or similar, weight as technical criteria, or even taken seriously, in the ultimate decision. See Part V for further discussion of the efficacy of these criteria in siting decisions.

114. State agencies are often free to ignore and override such concerns, even when expressed by local officials. In Pennsylvania, the State may refuse to follow a local government's recommendation to deny a facility permit, but if it does, a "written justification" must accompany the decision. See 35 PA. CoNS. STAT. ANN. \$ 6018.504 (West 1993); see also supra Part I.C and infra Part III.D. (noting opposition from both Chester residents and the city council to the recently permitted SRS facility); see also GERRARD, supra note 44, at 124 (noting that 24 of the 37 existing state siting statutes do contain preemption provisions, but mostly in the weaker form of state override authority).

115. See SUNSTEIN, supra note 81 , at 3-4 ("[W] hen the state chooses 'status quo neutrality,' in taking existing social practices and distributions as its baseline for being neutral toward public and private actors, it produces injustice."); see also Ford, supra note 82, at 1852 (making similar point in the context of housing segregation).

116. Kathy S. Northem, Battery and Beyond: Tort Law Response to Environmental Racism, 21 WM. \& MARY ENvTl. L. \& Pol'y Rev. 485, 523 (1997). 
environmental risks and benefits. ${ }^{117}$ It also encompasses the concept of environmental equity, which holds that all populations should bear a fair proportion of environmental contamination and health risks. ${ }^{118}$ These conceptions of environmental justice, again heavily reliant upon a distributive paradigm, are too monolithic. Injustice manifests itself in different ways for different social groups and can be seen and measured along a number of axes. ${ }^{119}$ Conceptualizing social harm only in distributive terms leaves different measures of injustice unnoticed and unheeded. ${ }^{120}$

For instance, consider Native Americans who in some instances have "chosen" to develop hazardous waste facilities on their land. Their decisions to do so have attracted both internal and external controversy. Internal controversies often involve the complex relationship between tribal members and their representative tribal councils, who often make these decisions in tandem with either the federal government or private developers. ${ }^{121}$ External controversies often involve neighboring

117. For example, a proposed "Environmental Justice Act" took exactly this approach to remedying the problem. That Act would have prevented the siting of toxic chemical facilities in environmental "high impact areas" if it could be demonstrated that adverse health consequence have resulted from the level of toxic emissions in those areas as compared to other areas. See H.R. 5326, 102d Cong. (1992). See also, Part V A infra (discussing similar state legislation). To be sure, equal distribution is not all that environmental justice entails. See, e.g., Robert D. Bullard, Decision-Making, in The Faces of ENvirommental Racism, supra note 1, at 3-28 (setting out the elements of environmental justice, including procedural equity, social equity, and geographic equity in environmental decision-making). While theoretical concepts and models of environmental (in)justice are multi-faceted, highlighting the empirical basis of environmental injustice and the emphasis on regulating distribution tends to overshadow the other elements of this phenomenon.

118. See 1 Environmental Equity Workgroup, U.S. Environmental Protection Agency, Pub. No. EPA 230-R-92-008, ENvironmental Equity: Reducing RisK For All Communities, WORKGROUP REPORT TO THE ADMINISTRATOR 1 (1992) [hereinafter ENVIRONMENTAL EQUTTY]; 2 Environmental Equity Workgroup, U.S. Environmental Protection Agency, Pub. No. EPA 230-R-92-008A, ENVIRONMENTAL EQUity: Reducing RISK FOR All CoMmunities, SUPPORTING DOCUMENT (1992) [hereinafter ENvironmenTal EQUiTy SUPPORTING DOCUMENT].

119. See, e.g., YouNG, supra note 3, at 39-65 (describing five conditions of oppressionexploitation, powerlessness, cultural imperialism, violence, and marginalization-and arguing that the existence of any one of the five is sufficient to call a group "oppressed"). For example, women may be subject to four oppressive conditions: exploitation, powerlessness, cultural imperialism, and violence; white gay men may be subject to only two of them: cultural imperialism and violence; while African Americans and Latinos may be subject to all five forms of oppression. See id. See also Pulido, supra note 4, at 152 (noting that "racism experienced by different segments of the population may vary considerably, depending not only on one's gender, 'race,' and class, but also the different meanings associated with these identities at any given moment').

120. Pulido, supra note 4, at 152 (noting that "it is entirely plausible that the racism at work in the placement of an incinerator in a black, rural community is different from the racism which causes Latinos to face severe occupational hazards").

121. For example, a well known eontroversy involves the Mescalero Apache and their decision to build a temporary nuclear waste storage facility on the Mescalero reservation in New Mexico. The project would allow approximately thitty utilities to place spent-fuel rods from commercial nuclear power plants in large casks and ship them to an above-ground storage facility on the reservation. The casks would have remained there for forty years or more, depending on whether or when the United 
communities or environmental groups claiming that the proposed siting will threaten natural resources or public health. ${ }^{122}$ Indisputably, commercial waste vendors are attracted to Native American communities because they are impoverished and often desperately in need of

States Department of Energy builds a permanent national repository for the wastes, which remain dangerously radioactive for tens of thousands of years. Tom Meersman, Mescaleros' OK of Nuclear Waste Storage Site Pits Tribe against $N$. Mexico Officials, Minneapolls STAR Trub., Mar. II, 1995, at $1 \mathrm{~A}$.

The proposed development was intensely opposed by tribal members, state officials, and other concerned citizens. Tribal officials estimated, however, that over the forty years it proposed to care for the waste, the fees would bring the tribe $\$ 250$ million in wages, lease payments, and other economic benefits. So confident was Wendell Chino, the president of the Mescalero Apaches, that he put the proposal to a vote by the entire tribe in January 1995. Turning out in record numbers, tribal members voted 490 to 362 against building the dump. See id. But, after a controversial petition drive headed by the reservation's housing director, the tribal council held a second ballot in Mareh 1995, in which the tribe, again turning out in record numbers, voted 593 to 372 in favor of the facility. Because the housing director's office provides housing to $60 \%$ of the tribe's members, many opposed to the project claimed that residents may have felt intimidated into signing the petition. See id. In addition, opponents charged that tribal members were "dcluged with false assurances about the safety" of the waste storage plant and "promised $\$ 2,000$ cash awards." Id. Tribal officials, on the other hand, blamed outside interference from "environmentalists" and other "anti-tribal" groups, as well as a misunderstanding of the benefits to be gained by the project, as an explanation for the first vote rejecting the plan. Id.

In April 1996, the project was suspended after negotiations between the utilities and tribal leaders failed. In 1997, the utilities signed an agreement with the Skull Valley Band of Goshute in Utah to lease a small portion of the tribe's reservation for the nuclear waste site. See George Johnson, Nuclear Waste Dump Gets Tribe's Approval in Re-Vote, N.Y. T1MES, Mar. 11, 1995, at A6; George Johnson, Tribal Democracy; Apaches Spurn a Chance to Run a Nuclear Dump, N.Y. TimEs, Feb. 5, 1995, at D2; Tom Meersman, NSP Nuclear Waste May Be Utah-Bound; Deal with Tribe Is under Fire, Minneapolis STAR TruB., Jan. 9, 1997, at 1B; Tom Meersman, NSP's Talks on Nuclear Waste Break Off; Storage Sought in New Mexico, MinNeapolis STAR TrIB., Apr. 19, 1996, at 8A.

122. An example of this type of conflict is the controversy surrounding the Califomia Tribe of the Campo Band of Mission Indians' commercial solid waste and recycling facility project. Having gained a thorough understanding of the economic and environmental issues that might arise, the Band decided to proceed with the project. Relying on federal regulations prohibiting discriminatory effects in the administration of federally subsidized environmental programs, see supra note 50, the tribe was able to develop its own waste codes and regulations that prohibited the processing and disposal of any hazardous waste within the reservation. The tribe also set up its own agency, the Campo Environmental Protection Agency (CEPA). The tribe charged CEPA with developing a solid waste management plan for the reservation, which would include codes and detailed regulations CEPA would be responsible for enforcing. Their codes not only complied with minimum federal standards, but were more stringent than California standards. As such, CEPA will have the most stringent and aggressive environmental program in California. See Palma Repole, One Tribe's Development of a Commercial Waste Facility in the Wake of Environmental Racism, 1 GREATER N. CENTRAL NAT. RESOURCES J. 209, 225-41 (1996).

Neighboring state residents opposed and tried to stop the Campo project for fear it would threaten their only groundwater aquifer. This objection was largely overcome by a decision of Bureau of Indian Affairs (BIA) that both recognized the potential problem for groundwater monitoring and concluded that an intensive system of monitoring wells could rcmcdy the deficiency and provide adequate protection. The lease to the developcr was approved on this basis, despite intense opposition, which included an unsuccessful attempt by neighboring communities and the County of San Diego to enjoin the Secretary of Interior's decision. See id. 
economic resources. ${ }^{123}$ Tribal governments sometimes view these projects as providing tribal economic self-sufficiency, including full employment of tribal members and investment capital for future projects. ${ }^{124}$ Moreover, as some have noted, despite situations of desperate poverty, tribal governments, because of the activism of tribal members, have prudently rejected proposals for environmentally unsound sites on their reservations. ${ }^{125}$

Native-American advocates resist efforts to force their struggles into a narrow distributive paradigm of environmental racism. Instead of measuring environmental injustice according to how many waste sites exist on tribal lands, some Native Americans have focused on their tribes' ability to exercise their unique sovereignty. ${ }^{126}$ This sovereignty includes the right to make decisions and have them respected, which means that "the environmental community must come to understand that not all such facilities are unwanted by the host community and that, in those cases where a community wishes to have such a facility, its decision is to be respected." 127

123. Moreover, waste companies are capitalizing on the confusion surrounding environmental regulatory authority on Indian lands. State law does not apply to lndian lands if it is preempted by federal law or its imposition would unduly interfere with the tribe's ability to regulate and govern its own affairs. See id. at 216-17. This means that waste projects on Indian lands effectively escape the more stringent environmental regulations imposed under state law, making them especially attractive sites for companies who wish to save the extra cost of compliance. See id. To complicate matters further, the original federal environmental statutes failed to recognize tribes as sovereign entities, the equivalent of states, for purposes of the Acts. See id. While in the 1980s most of the statutes were later amended to include tribes, the Resource Conservation and Recovery Act (RCRA), which sets minimum guidelines and standards for the disposal of hazardous and solid wastes, has yet to be revised. Consequently, there is currently no provision for solid waste regulation on Indian lands that do not exercise independent means and regulate themselves. See id. at 218-19; see also Backcountry Against Dumps v. EPA, 100 F.3d 147 (1996) (holding that Native-American tribes are not states under RCRA).

124. See Kevin Gover \& Jana L. Walker, Escaping Environmental Paternalism: One Tribe's Approach to Developing a Commercial Waste Disposal Project in Indian Country, 63 U. Colo. L. REV. 933, 941 (1992) (describing use of the investment capital from the Campo Project to fund badly needed services on the reservation, provide full scholarships for any tribal member admitted to college, refurbislı all existing tribal facilities and constructing new ones, establish a tribal housing authority, construct new homes for every family now living in substandard housing, and provide income supplements to cach tribal member).

125. While tribal governments across the U.S. have received many proposals from waste companies, only a handful remained under serious consideration as of 1992 . See id. at 934.

126. As one Native Ameriean tribal member explains:

The ability of tribal governments to exercise sovereign powers to determine social, economic and scientific policy is as fundamental as the exercise of cultural and religious freedom. A definition of enviroamental jnstice which applies to tribes must go beyond the standard definition which ealls for 'equal protection from environmental and health hazards across racial, class and cultural groups.' Tribes themselves must develop their own policies which are rooted in the principle that tribes have the right to excise sovereiguty and determine policy on tribal lands.

Kimberly TallBear, Environmental Justice: Tribes Take a Stand on Nuclear Waste Storage, CoLors, Fall 1996, at 11, 13; see also Repole, supra note 122, at 240-41.

127. Gover \& Walker, supra note 124, at 933. 
Environmental racism manifests itself quite differently in the case of Native Americans, reflecting a particular racial ideology rather than measurable acts of discrimination. When tribal sovereignty is not respected, Native-American groups often find themselves fighting racial paternalism and cultural imperialism. ${ }^{128}$ Tribes are faced with having to prove, to both environmentalists and politicians alike, that they are competent enough to manage their land and natural resources in a way that removes the incentive for abusive waste projects and preserves the integrity of tribal sovereignty. ${ }^{129}$ As the counsel to the Campo Band of Mission Indians in their battle to develop a tribal waste project explains, the "major issue" facing tribes in this context is not "environmental," but instead one of "power and racism." He criticizes the mainstream environmental community for its assumption that "if an Indian community decides to accept such a project, it either does not understand the potential consequences or has been bamboozled by an unprincipled waste company." This assumption is "clearly" a "racist" one; it implies "that Indians lack the intelligence to balance and protect adequately their own economic and environmental interests." Moreover, it is "the same assumption that guided the federal policies that very nearly eradicated Indian people in the late nineteenth and early twentieth centuries." As such, it is "environmental racism" and ultimately "every bit as destructive as the open hostility to Indian people that we experience in many parts of this country." $" 130$

Another type of opposition to a tribe's decision to locate a waste facility on their land is equally problematic. Some object that tribes' "spiritual view" and values are incompatible with the economic development promised by a potential facility. Addressing one environmentalist's suggestion that Tribes are being "forced" to "exchange the spiritual view of their once pristine environment for a commercial one, ${ }^{\prime 131}$ a Native-American activist posited that not only are Indian Reservations "situated on the least desirable land in the nation," but the

128. See supra note 119.

129. In fact, far from the perception that the waste industry is "beating a path to the tribal door," the bigger problem on Native lands is the unauthorized and illegal dumping occurring on reservations. See Gover \& Walker, supra note 124, at 934 ("For most Indian communities the problem of open dumping on tribal lands is of much greater concern than the remote prospect that a commercial waste disposal facility may be sited on a reservation.").

130. Id. at 942-43.

131. Roger R. Martella, Jr., "Not in My State's Indian Reservation"-A Legislative Fix to Close an Environmental Law Loophole, 47 V AND. L. REv. 1863, 1864-65 (1994) (noting also that "this shift from nurturing nature to exploiting the environinent on a growing number of reservations results Iargely from a legal loophole that permits non-natives to pollute inside Indian eountry in ways they could not elsewhere"); see also Albuquerque v. Browner, 97 F.3d 415, 427 (10th Cir. 1996) (stating that the City of Albuquerque's arguments against the EPA's approval of Tribe's more stringent water quality standards includes claim that the "water quality criteria approved by the EPA fail to protect water used under the [tribe's religious] ceremonial use standard"). 
land "is usually so barren that farming is impossible and ranching avenues are pitiful." 132 As such, the tribe's "spiritual view" has "often been already shattered by white development of what was once their traditional domain." 133 To some Native Americans, this "spiritual incompatibility" objection reflects either a "nostalgic need to maintain a romantic[] fiction about Indians and their relationship with 'Mother Earth" "or "a prevailing racist attitude that Indian people have no business developing the natural resources of their land without the say-so of the non-Indian community." 134

The unique characteristics of Native-American environmental struggles illustrate the epistemological inadequacies of a distributive paradigm of environmental injustice. A distributive notion of environmental injustice does not capture the cultural imperialism and paternalism that Native Americans endure. As one Native-American activist explains, "For many poor, but competent Tribes, the choice to build a waste facility is the lesser of two evils. Advocates of Tribal rights would argue that the insidious presence of 'environmental racism' is inherent in the choosing, not in the choice."135

\section{III}

A CLOSER LOOK:

Evaluating (IN)Justice at THE GRASSROOTS LEVEL

In the preceding Part, I argued that the failure to articulate the causal structure of distributive outcomes has imperiled our full understanding of environmental racism or injustice. I also suggested that distributive environmental outcomes are produced by, and withm, a system of social relations and social structure. Only by understanding the system of social relations and structure in which environmental distributions take place can we begin to understand the phenomenon of environmental injustice, and what environmental justice would entail. This Part will situate the role of grassroots struggles in this epistemological project before returning to a more detailed account of the Chester experience.

Grassroots struggles are a window into the social relations and processes underlying distributive outcomes. To be sure, they are not the only window imto this process. Importantly, however, grassroots accounts tell a crucial narrative that "reveals the particular experiences of those in social locations, experiences that cannot be shared by those situated differently but that they must understand in order to do justice

132. Repole, supra note 122 , at 221 .

133. Id.

134. Id. at 221-22.

135. Id. at 241. 
to the others." ${ }^{\prime 36}$ As I have indicated earlier, many books on the subject illustrate that narratives of disaffected communities are important to our understanding of the normative content of claims of injustice in environmental decision-making. ${ }^{137}$ As importantly, grassroots struggles can help policy-makers understand the way in which individuals in disaffected communities experience the very social and structural constraints upon which the siting process relies. Such an understanding, one hopes, will help reconceptualize grassroots efforts as more than mere attempts to disrupt the decisions of private corporations and state agencies. Rather, grassroots struggles are a crucial arena of restructuring social relations in systems of localized environmental decision-making.

An important component in the environmental justice debate concerns the relative power and agency of the actors involved. Grassroots struggles frequently pit low-income and/or minority communities against the facility owners and state environmental agencies. By virtue of their social status, the communities often appear vulnerable to more powerful interests in the decision-making process. ${ }^{138}$ On the other hand, some commentators believe that citizens in overburdened communities possess enough power to choose freely whether to host a hazardous waste facility or to employ "exit" as a response to the siting of a locally unwanted land use. ${ }^{139}$ In addition, recent books are replete with stories that portray overburdened communities as powerful enough to successfully defeat siting efforts by private and public interests. ${ }^{140}$

The competing views, and realities, of power and agency, in grassroots environmental justice struggles raise some important questions. How can these communities be both powerless and vulnerable to unwanted sitings, yet powerful enough to stop these sitings? If these communities are successful in fighting off unwanted uses, then where is the

136. Iris M. Young, Communication and the Other: Beyond Deliberative Democracy, in Democracy and DifFerence 120, 131 (Seyla Benhabib ed., 1996).

137. See supra note 1 and accompanying text.

138. See, e.g., Bullard, supra note 106 , at 82,85 (arguing that the NIMBY syndrome has resulted in private industries shifting their siting efforts to "poor, powerless, minority communities" which "do not have resources, or [government and industry] contacts, to initiate or sustain the proactive behavior found in more affluent communities"); Regina Austin \& Michael Schill, Black, Brown, Poor, and Poisoned, in Unequal Protection, supra note 1, at 55 ("People of color in the United States have traditionally had less clout with which to check legislative and executive abuse or to challenge regulatory laxity. Private corporations, moreover, can have a powerful effect on the behavior of public officials. Poor minority people wind up the losers to them both.").

"NIMBY" stands for Not In My Backyard. See generally KeNT E PORTNEY, Siting Hazardous Waste Treatment Facilities: The NIMBY Syndrome 10-14 (1991).

139. See, e.g., Blais, supra note 69, at 126 ("Ultimately, many members of the host community may express their preferences concerning residential proximity to environmentally sensitive land uses with their feet."). Of course, social processes like racial discrimination limit the choices, and mobility, of individuals in these communities. See Been, supra note 74, at 1389-90.

140. See supra note 1. 
need for policy reforms? Why not let this new version of "NIMBYism" drive the market for distributing land uses, as it has up to now? If communities such as Chester have enough power to stop unwanted sitings, why the need for policy reforms to achieve environmental justice?

Grassroots struggles, such as that in Chester, reveal a much more complex view of agency ${ }^{141}$ and power relations than has been generally offered in the context of the environmental justice debate. For many involved in the struggle for environmental justice in disadvantaged communities, agency is neither transcendent ${ }^{142}$ nor nonexistent. ${ }^{143}$ The fact that communities such as Chester are both vulnerable to toxic assault and, simultaneously, are successful in stopping that assault suggests a paradoxical combination of socially oppressive constraints and selfdetermining capacities.

Feminist scholars have recently articulated a view of power and agency, applicable to grassroots environmental justice struggles, which goes beyond the traditional dominant-subordinate model. Collective resistance in communities such as Chester, amidst social and structural

141. My use of the term "agency" in the context of this Section mirrors its use in recent feminist literature. Like Kathryn Abrams, 1 use the term "in a way that acknowledges an internal, as well as an external or outwardly-oriented, aspect to agency, and that highlights the oppressed circuinstances of many who seek to exercise it." Kathryn Abrams, Sex Wars Redux: Agency and Coercion in Feminist Legal Theory, 95 Colum. L. REv. 304, 307 n.11 (1995). Agency thus denotes the "ability to develop and act on conceptions of oneself that are not determined by dominant, oppressive conceptions." Id. The term agency will frequently be used with the term "resistance" because poor people of color's agency under oppression "is necessarily partial or constrained," because of "structures and practices that operate to deny or mitigate that capacity," and is "frequently directed toward resisting those structures [and] practices." Id.

142. See id. at 346 (describing feminist critics who focus exclusively on women's capacity for self-direction and resistance and their ability to overcome the powerlessness created by patriarchal constraint as embracing "transcendent agency").

143. Grassroots successes have demonstrated that well organized grassroots groups are not powerless in the sense of having no, or little, power-political or otherwise. Grassroots struggles can be viewed as a crucial arena for restructuring power relations in a system of localized decisionmaking, where environmental justice activists are dynamic agents in that reconstruction. This view of power is Foucaultian in that it understands power as an ongoing process of social construction in which both the dominant and subordinate are participating agents. As Steven Winter has writtcn:

To understand power as a property of a social system of relations is to see power as a shared resource that can be activated from many different positions within that system. Once power is understood as relational, it becomes apparent that at least some of what the dominant "have" must already be available to the subordinated. Indeed, there is an important sense in which this second point is the same as the first. The deconstruction of power is also the deconstruction of the agency and autonomy of the traditional liberal subject. This means that responsibility for subordination and inequality cannot be localized in certain identifiable agents; it is widely distributed throughout the social network. To the exact degree that this understanding of power diminishes the agency of the dominant, it amplifies the agcncy of the subordinated. What it subtracts from one part of the network, it necessarily redistributes to the other.

Steven L. Winter, The "Power" Thing, 82 VA. L. REv. 721, 835 (1996) (interpreting Michel Foucault's conception of power as not a "thing" nor quality, capacity, or possession of particular people; but rather as an emergent quality than can only take shape through the joint agency of all those who participate in a given set of social relations). 
constraints, reflects individuals operating with "incomplete agency."144 Viewed within the context of incomplete agency, the choices and actions of individuals in grassroots struggles are "neither fully free nor completely determined." 145 Instead, they are influenced by independent self-conceptions, or internal agency, and the reality of broader patterns of oppression. ${ }^{146}$

This richer, more complex view of power and agency in vulnerable, yet resistant, communities forces us to scrutinize the forces, or mechanisms, which render the agency of some actors incomplete. For instance, such scrutiny will require an analysis of those forces that mediate between agents in a social relationship, so-called "third agents," which allow the "powerful" to enact and reproduce their power. ${ }^{147}$ This analysis, in turn, necessitates an analysis of the legal and regulatory context in which these struggles take place. The legal and/or regulatory context either independently may constrain the agency of disaffected individuals or, alternatively, facilitate the constraints imposed by others in the social structure.

A close study of grassroots strnggles helps unmask the social and structural constraints operating in a local system of environmental decision-making and underlying the distributive outcomes. ${ }^{148}$ We can see the many dimensions of power struggles, the relationships of actors within that struggle, and the role of the siting process in structuring those relationships. Focusing on the structural dynamics of a grassroots struggle, particularly as they interact with the state/public apparatus, also shifts the focus away from individual actors and the fruitless search for clearly identified perpetrators and victims. The focus appropriately shifts toward the structured nature of decision-making power. This more

144. Cf. Abrams, supra note 141, at 347-48; see also Tracy E. Higgins, Democracy and Feminism, 110 HaRv. L. REv. 1657, 1696 (1997).

145. Cf. Higgins, supra note 144 , at 1691 .

146. See Abrams, supra note 141, at 348 ("As contrasted with transcendent agency, internal agency is hard-won and almost always partial or incomplete. So long as coercion and devaluation of women continue in society, women must struggle with the tension between the 'outside' and 'inside' visions of themselves, or among the multiple voices that make up their identities.").

147. As Iris Marion Young explains:

One agent can have institutionalized power over another only if the actions of many third agents support and execute the will of the powerful. A judge may be said to have power over a prisoner, but only in the context of a network of practices executed by prison wardens, guards, record kecpers, administrators, parole officers, lawyers, and so on. Many people must do their jobs for the judge's power to be realized, and many of these people will never directly interact with either the judge or the prisoner.

Young, supra note 3 , at 31 .

148. As Luke Cole has written:

Engaging in what some critical race theorists and critical legal scholars have called "unmasking", grassroots activists have uncovered, through their own experiences, the hidden power dynamics of pollution and environmental laws. They have acquired an "institutional" understanding of the political economy of pollution.

Cole, supra note 7, at 642-43 (footnotes omitted). 
structural focus, in turn, can lead to fruitful discussions about the role of siting process reforms in achieving environmental justice.

IV

The StRUgGle For ENVIRONMENTAL JUSTiCe in Chester, Pennsylvania

In the early 1990s, Chester's residents banded together to fight back against what they viewed as an all-out attack on their community's quality of life and health. At this point, Chester was hoine to the Westinghouse incinerator, which is one of the country's largest waste incinerators, the DELCORA sewage waste treatment facility, the Abbonizio Recycling facility, and various older industrial operations. ${ }^{149}$ The DEP was on the verge of permitting an infectious medical-waste sterilization plant next to the Westinghouse incinerator. Concerned residents attended a public ineeting in October of 1992, convened by the City's first Democratic mayor. ${ }^{150}$ Billed as a town meeting, it drew representatives from the EPA and the DEP, local government officials, and private industry. The residents aired their complaints about the facilities-odors, dust, noise, and trucks carrying trash to the facilities. Industry and government representatives offered responses such as, "Do you think your government would do something wrong to you? Do you think [we would allow this facility if it did not] meet all of the federal and state regulations?'"151 At least one resident found the attitude of the representatives condescending. Zulene Mayfield stood up, introduced herself, and told the representatives, "I can't understand why you bright, college-educated people can't come down here and tell a better lie than what you're telling. [W]e are people from probably the worst school district in the state and we can see [and] understand these lies...."152 Zulene got up and left. From that point on, Zulene attended the weekly meetings of concerned residents of Chester. Eventually, Chester Residents Concerned About Quality of Life (CRCQL) formed, with Zulene at the helm.

\section{A. $\quad$ Fighting Back and Running Up against a Wall of Exclusion}

The initial meetings with industry and government officials foreshadowed a pattern of stonewalling that emerged every time the

149. See supra Part I.

150. See infra Section IV.D.

151. Interview with Zulene Mayfield, chairperson of CRCQL, in Chester, Pennsylvania (Apr. 14, 1996) [hereinafter Mayfield Interview].

152. Id. Unless otherwise noted, all factual background and quotes in this Part are from the Mayfield Interview, supra note 151. 
community sought information and solutions from industry and government. CRCQL first set out to have one-on-one meetings with individual facility owners, city officials, and state officials. All these meetings, however, ended in a similarly disappointing fashion. The residents came to the meetings to complain about existing problems, yet the same problems surfaced week after week. Meetings ended with no resolution in sight and residents' questions left unanswered. No one seemed willing to take any responsibility for the problems the residents of Chester faced. A facility representative would tell CRCQL members, "Well, your problem is not exactly our problem," and then direct them somewhere else. Zulene Mayfield recounts that she felt like she was "a gerbil on a habitrail," running and never getting anywhere.

Eventually, the residents got fed up with the stonewalling. They decided to sit all facility and government representatives together and "watch them point fingers at each other," instead of telling the residents to go talk to someone else. CRCQL arranged another meeting of local and state agency officials, as well as representatives from the Chester facilities. The confrontational dynamic expected at the meeting never materialized. Government and industry representatives seemingly agreed to divulge as little information as possible. For example, prior to the meeting, there was a fire at the Westinghouse incinerator. Many people from the community came out in force to photograph and tape the commotion surrounding the nuinerous pieces of emergency equipment employed to fight the fire. At the ineeting, when the Westinghouse representative was asked about the fire, he denied any fire had occurred. The residents were dumbfounded; they had photographed and taperecorded a fire at the facility. Now, the company's representative was denying its occurrence. During subsequent meetings, CRCQL continued to challenge Westinghouse's denial. However, even when the fire chief presented CRCQL and the Westinghouse representatives with documentation of the fire, the company still denied there had been a fire. This and other incidents made the residents feel belittled, as if Westinghouse deliberately decided: "Well, we had a fire but let's tell them, 'We didn't have a fire,' and that's it. We'll offer no explanation to them."'s3 As Zulene recalled, it was "very demeaning."

The government and industry officials' conduct at the meetings exemplified the ways in which the decision-making process had excluded the residents all along - as if they did not inatter. Moreover, it seemed as though various tactics were employed to keep the residents in the dark about issues fundamentally affecting their health and quality of life. For instance, one of the barriers residents initially faced was an inability to understand the highly technical language the facility

153. Id. 
representatives used. When a resident attempted to speak in an open meeting to a Westinghouse representative about the incinerator, the representative immediately corrected the resident, telling her that it was a resource recovery facility. ${ }^{154}$ This tactic played on the lack of sophistication of the Chester residents and effectively silenced them. As one resident remarked, "Every meeting we left feeling like our tail was between our legs, because they always tried to make us think that what was happening was not happening." 155 Believing that "intelligence" is an "equalizer," CRCQL members sought to familiarize themselves and other Chester residents with the terminology and technology of the facilities. ${ }^{156}$ Nevertheless, even as the residents educated themselves, government and industry representatives continued to ignore them. Meetings with facility representatives were completely unsatisfactory; the residents felt unacknowledged and unheard.

\section{B. Taking Direct Action}

Refusing to surrender to government and industry stonewalling, and seeing no other alternative, CRCQL took more direct action after two important realizations. First, concerned residents tried to work through the system-acquirmg technical knowledge about the facilities, reading all of the public docuinents, and requesting information from decision-makers-but realized that their concerns would not be addressed, much less resolved, in that manner ${ }^{157}$ Second, CRCQL felt that decision-makers consistently demonstrated a lack of respect toward residents trying to obtain further information about the facilities.

On a cold day in December 1992, the residents held their first protest, focusing on one of the most visible and audible invasions into their city-the trucks carrying waste to the Westinghouse incinerator. On the morning of December 22, ten to fifteen residents, mostly senior citizens, lined Thurlow Street in Chester to stop the trucks from reaching their destination. Other residents joined in the protest on their lunch break. Westinghouse finally responded after residents physically refused to let the trucks take their load to the Westinghouse facility for up to two hours. Westinghouse's chief financial officer flew to Chester during the

154. Arguably there is not much of a substantive difference between the two, other than semantics. The storage and processing of solid waste is regulated under the Resource Conservation and Recovery Act of 1976, Pub. L. No. 94-580, 90 Stat. 2795 (now codified at 42 U.S.C. \$ 6901-87) (West 1995) (RCRA). RCRA defines a "resource recovery facility" as one "at which solid waste is processed for the purpose of extracting, converting to energy, or otherwise separating and preparing solid waste for reuse." 42 U.S.C. $\$ 6903(24)$ (West 1995). Iricineration is one way of treating and/or precessing solid wastes. The Westinghouse facility is a trash-to-energy incinerator.

155. Laid to Waste, supra note 14.

156. Mayfield Interview, supra note 151.

157. See id. 
protest to meet with the residents. After hearing their story, Westinghouse officers agreed to build a new road for the trucks hauling trash to the incinerator. Although the new route was built only one block away, the residents felt this protest was a success. ${ }^{158}$ For the first time simce they had begun to stand up and voice their opinions, they felt empowered. As Zulene explained, "It was really important [for Westimghouse] to understand that ... this is important enough to stop Christmas shopping, to stop the season, ... to let [them] know that we have a problem and we don't care how cold it is." The residents also realized that they needed to hit Westinghouse where it hurt-in its bank account. Thwarting normal business operations furthered this objective.

Despite the message of resistance sent by the protests, in July 1993, the DEP issued a permit for the construction and operation of yet another facility in Chester. The community learned that Midlantic BioWaste Systems Inc., a subsidiary of Thermal Pure Systems (Thermal Pure), planned to build an infectious medical waste sterilization plant next to the Westinghouse incinerator. The proposed facility's operators planned to sterihze medical-chemotherapeutic waste through a process called autoclaving. ${ }^{159}$ They would then package and ship the waste to a landfill. For Chester residents, this was the last straw-the Thermal Pure facility compounded an already intolerable situation. CRCQL mobilized the Chester residents and gathered more than 500 signatures in opposition to the project. They gave these signatures to the DEP and the City Council as evidence of their opposition to the facility. In response, the company withdrew its permit application, originally filed under the corporate name of Midlantic BioWaste Systems, and reapplied under the name Thermal Pure. Again, this was nothing new. Zulene easily realized they were "hiding behind names."

Unfortunately, the residents then uncovered an even more entrenched barrier-local politics. All of the city council members except for the inayor sent a letter to the governor and to the DEP asking them to expedite the permitting of Thermal Pure. ${ }^{160}$ Not surprisingly, the DEP granted Thermal Pure's permit without holding a public hearing and virtually ignoring the residents' concerns. To the residents' dismay, the legal requirement designed to include them in the decision-making process ultimately denied the residents any opportunity to participate in the process. In Pennsylvania, as in other states, permit applicants must

158. See MENDEL-ReYes, supra note 17 , at $153-58$ (recounting the Chester protest).

159. Autoclaving sterilizes objects in an apparatus using superheated steam. Chester Residents Concerned For Quality Living v. Commonwealth of Pa., Dep't of Envtl. Resources, 668 A.2d 110, 111 n.1 (Pa. 1995).

160. See Mayfield Interview, supra note 151; Andy Murray, Waste Treatment Facilities in Chester (visited Nov. 12, 1997) <http://www.envirolink.org/orgs/pen/crcql/facilities.html> (CRCQL Web Page). 
publish formal notice of their proposed facility in local newspapers to give the public an opportunity to comment on and learn about the facility ${ }^{161}$ However, this requirement often provides inadequate notice to, in particular, low-income communities, where literacy levels are low, and it is unlikely that many citizens will become aware of or read the official notice. ${ }^{162}$ For instance, as happened in Chester, it is not uncommon for notice of a permit application to be placed in a minuscule space at the back of the local newspaper. ${ }^{163}$ Once again, the residents felt the decision-makers had excluded them. The residents opined that "[b]y not holding a public hearing, DEP was saying that there was no known public opposition to Thermal Pure, in spite of the 500 plus signatures they had in opposition."164

\section{A Hard Lesson: Environmental Justice as a Political, Not a Legal, Issue}

A Philadelphia public interest lawyer, Jerome Balter, read an article about the Chester protest and decided to call CRCQL. This call began a long-term relationship between Balter and CRCQL. Through Balter's efforts, the residents discovered yet another weapon in their fight against the facilities-legal action. In August 1993, one month after the Thermal Pure permit was issued, Balter appealed the Thermal Pure

161. See 25 PA. CODE $§ 271.141$ (West Supp. 1997) (listing public notice and comment as general requirements for permits and permit applications). This section requires that the permit applicant publish notice of its application once a week for three consecutive weeks in a "newspaper of general circulation in the area where the proposed facility is located." Id. Permit applicants must also give separate notice via certified mail to "owners and occupants of land contiguous to the site or the proposed permit area." $I d$. This notice is intended to give the community a formal opportunity to review applications and comment on them within a specific period of time.

162. See Omar Saleem, Overcoming Environmental Discrimination: The Need for a Disparate Impact Test and Improved Notice Requirements in Facility Siting Decisions, 19 CoLum. J. ENvTL. L 211, 240-41 (1994).

163. See Mayfield Interview, supra note 151 . On the other hand, "local [officials] are given a separate, formal opportunity to comment on municipal waste facility permit applications." Waste Management Permits (visited Nov. 8, 1997) <http://www.dep.state.pa.us/dep/DEPUTATE/enved/ go_with_inspector/resource/Waste_Manage_Permit.htm.> (Pa. Dep't of Envtl. Protection Home Page). Once the applicant submits its application to the DEP, it must send a copy to the city. See 25 PA. CODE $\S 271.141$ (d) (West Supp. 1997). City officials are then free to raise objections, or give their support, directly to the DEP. If, as in this case, local officials are in favor of a facility for economic reasons, the community's health and quality of life concerns are not likely to be raised or addressed in the decision-making process.

164. Russell, Perpetrators, supra note 26. The relevant section is more permissive than mandatory. See 25 PA. CODE $\$ 271.143$ (a) (West Supp. 1997) ("The Department may conduct public hearings for the purpose of receiving information on an application for a new permit... wherever there is significant public interest or the Department deems a hearing appropriate."). 
permit on CRCQL's behalf. ${ }^{165}$ In its appeal, CRCQL claimed that the permit issued to Thermal Pure and the accompanying regulations promulgated by the DEP violated the Pennsylvania Infectious and Chemotherapeutic Waste Disposal Act (Disposal Act), which the legislature enacted to control waste flow in Pennsylvania. ${ }^{166}$

Pursuant to the Disposal Act, the DEP promulgated the Infectious and Chemotherapeutic Waste Plan (Waste Plan). The effect of the Waste Plan was to divide Pennsylvania into three zones-eastern, central, and western-in order to regulate "incineration or other disposal" of infectious wastes. ${ }^{167}$ The DEP found that the eastern zone, which includes Chester and Philadelphia, generated 13,335 tons of infectious waste per year. ${ }^{168}$ Under the Waste Plan, covered facilities must obtain $70 \%$ of their waste from the zone in which the facility is located. The maximum capacity of a covered facility located within the eastern zone could be no greater than 10,765 tons per year. ${ }^{169}$ Thermal Pure's permit nevertheless allowed the facility to handle 105,000 tons per year, nearly ten times the maximum the Waste Plan allowed for a given facility in the eastern region, and nearly four times the waste produced by the entire state of Pennsylvania. ${ }^{170}$ In its appeal, CRCQL questioned how a facility with the capacity to treat four times the waste produced in the entire state could be legal under a statute that was intended to minimize waste transportation in Pennsylvania. ${ }^{171}$

165. The appeal was filed with the Environmental Hearing Board, which consists of a chairperson and four members, all administrative law judges appointed by the governor. The Board hears appeals from actions of the Pennsylvania DEP. See 25 PA. CODE $\S 1021.2(a)$ (West 1995).

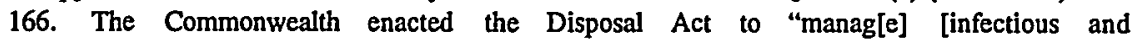
chemotherapeutic wastes] at their place of generation with a minimum of transportation ..... and [to ensure] that such wastes are best managed, processed and disposed of and rendered harmless by means of current state-of-the-art high-temperature incineration." $1988 \mathrm{~Pa}$. Laws 525 (codified as amended at 35 PA. Cons. Stat. $\$ \S 6019.1-6019.6$ (West 1993)). However, pursuant to the Disposal Act, the Pennsylvania legislature also directed the DEP to address the siting and distribution of facilities for the "incineration or other disposal" of infectious or chemotherapeutic wastes. Id.

167. "Infectious wastes are those contaminated by disease producing micro-organisms which may harm or threaten human health." Chester Residents Concerned for Quality Living v. Dep't of Envtl. Resources, 655 A.2d 609, 610 (Pa. Commw. Ct.), rev'd 668 A.2d 110 (Pa. 1995).

168. Id. at 610 . Of that 13,335 tons generated, approximately 5,800 tons per year are "incinerated or otherwise disposed [of]" at the sites where the waste is generated. Id. Thus, 7,735 tons per year must be transported from the places of generation to a covered facility for disposal. Id.

169. See id. This figure assumes that "all of the infectuous waste generated in the eastern zone were shipped to this single facility for incineration." Id.

170. The DEP found that the total quantity of infectious and chemotherapeutic wastes generated throughout all of Pennsylvania is 26,500 tons per year. See id. at 609 .

171. Simply stated, the legal issue on appeal was whether Thermal Pure's autoclaving facility constituted a "disposal" facility subject to the Disposal Act and Waste Plan. CRCQL believed that the DEP had violated the Act by not holding Thermal Pure to the standards set out in the Disposal Act, and therefore, that the permit issued was invalid. Since the Waste Plan promulgated by the DEP excluded from consideration all facilities other than commercial incinerators, Thermal Pure argued neither the Waste Plan nor the Disposal Act reached it. See Chester Residents, 655 A.2d at 611. 
In February 1994, the Environmental Hearing Board summarily dismissed CRCQL's claims. The Board ruled that the DEP Waste Plan did not govern the Thermal Pure infectious waste sterilization process and that its permit was valid. CRCQL refused to give up. It appealed the decision to the Pennsylvania Commonwealth Court. In February 1995, the commonwealth court adopted CRCQL's reasoning, overturned the Environmental Hearing Board ruling, and declared that the Thermal Pure permit was invalid. ${ }^{172}$ Thermal Pure then appealed to both the commonwealth court and the Pennsylvania Supreme Court for a stay of the ruling against them. Both requests were denied. Accordingly, the DEP issued a cease and desist order to Thermal Pure, forcing the company to suspend all further operations in Chester.

To CRCQL's amazement, their victory and the closure of Thermal Pure was short-lived. Under Pennsylvania law, Thermal Pure had the right to appeal the DEP closure order to the Environmental Hearing Board. ${ }^{173}$ Instead, the company directly appealed the DEP order to the commonwealth court. Thermal Pure filed a petition asking the commonwealth court to review its previous decision not to stay the cease and desist order. At the same time, Thermal Pure requested the Pennsylvania Supreme Court to exercise special jurisdiction and hear argument on the stay. To everyone's surprise, the supreme court granted Thermal Pure's request, issuing a stay of the cease and desist order pending its review of the case.

In taking the case from the commonwealth court, the supreme court employed a controversial, and extraordinary, legal maneuver. The supreme court invoked its "King's Bench" power to take the case from the commonwealth court. The King's Bench power originates from the Act that created the Supreme Court of the Commonwealth of Pennsylvania in 1722, which gave the court power coterminous with the highest courts in England. An 1836 revision of the Act establishimg the King's Bench power gave the court jurisdiction to stop all existing proceedings in a lower court, while it conducts its own review of a case. ${ }^{174} \mathrm{~A}$ later constitutional provision, entitled "extraordinary jurisdiction," seemed to limit the supreme court's King's Bench jurisdiction to cases

172. The Court rejected the DEP's and Thermal Pure's argument that the Disposal Act did not cover the type of activity-autoclaving, a type of medical sterilization-conducted by the Thermal Pure facility. Specifically, the Court reasoned that the plain language of the Disposal Act indicates that the legislature intended the Act to apply not solely to "incineration or other disposal" of infectious and chemotherapeutic wastes, but also to the collection, transportation, processing, and storage of those wastes. Hence, it found that the DEP Waste Plan violated the Disposal Act, because it failed to address the siting and regulation of sterilization facilities sucl as Thermal Pure. See id. at 612 .

173. See 35 Pa. Cons. Stat. ANN. $\S 755.5$ (West 1993) (establishing jurisdiction of the Environmental Hearing Board).

174. See Commonwealth v. Onda, 103 A.2d 90, 91 (Pa. 1954) (citing Act of May 22, 1722, $1 \mathrm{Sm}$. L. 131, 17 P.S. $\S 41$, and Act of June 16, 1836, P.L. $784 \S 1$; 17 P.S. § 41). 
of "immediate public importance"-consistent with the power's early beginnings. ${ }^{175}$ In spite of its normal conservative practice, there have been "a number of remarkable occasions" on which the supreme court has invoked its jurisdiction in a manner that has expanded the King's Bench power "beyond its original parameters." 176 This arguable overreaching has prompted the state legislature to revisit the question of the King's Bench power. ${ }^{177}$ Nevertheless, the supreme court took the case before the commonwealth court was able to hear Thermal Pure's appeal. The effect of this exercise of the King's Bench power was to deny CRCQL any chance at an appeal.

Prior to making its final decision, the Pennsylvania Supreme Court held a hearing on the DEP regulations and the Thermal Pure permit. CRCQL was invited to attend the hearing and chartered a bus to Harrisburg. The group arrived with high hopes because, as Zulene Mayfield said, they believed that "the law is the law and whatever the law says is right. Everybody has to adhere to the law." Sadly, for Zulene Mayfield and CRCQL, they were about to confront yet another tangible experience of institutional racism. Zulene recalls the look of "contempt" in the eyes of the justices as the group entered the courtroom. "I can't say it was a look of hate," she explains, but she "knew before we sat down in that court what the outcome was going to be."

Jerome Balter represented CRCQL at the hearing and has his own view of the proceedings. Noting that there was no transcript or recording of the hearing, Balter relates the atmosphere that prevailed in the room. A justice said to Balter, "Mr. Balter, if it were up to you a lot of companies would lose their permits." To which Balter replied, "I don't take any permits away. That's the DEP's job." The justice did not relent, "Yes, but you start those cases, don't you?" Balter responded, "Well, that's right. I would think, your Honor, that you'd be interested

175. 42 Pa. Cons. Stat. ANN. $§ 726$ (West 1981):

[N]otwithstanding any other provision of law, the Supreme Court may, on its own motion or upon petition of any party, in any matter pending before any court or district justice of this Commonwealth involving an issue of immediate public importance, assume plenary jurisdiction of such matter at any stage thereof and enter a final order or otherwise cause right and justice to be done.

Id. See also In re Petition of Blake, 593 A.2d 1267 (Pa. 1991) (construing section 726 as an elaboration of the King's Bench powers); Commonwealth v. Lang, 537 A.2d 1361, 1363 n.1 (Pa. 1988) (same).

176. Bemard F. Scherer, The Supreme Court of Pennsylvania and the Origins of King's Bench Power, 32 DuQ. L. REv. 525, 525-26 (1994).

177. See, e.g., Frank Reeves, Special Power of State Court Challenged, Pitrsburgh Post-GAzETTE, July 23, 1995, at Al (reporting on the House Judiciary Committce's plans to hold hearings on King's Bench power and the Thermal Pure decision and noting that state representativcs have questioned the power in the past). 
in having the law defended and applied properly." The justice had the final word, "Mr. Balter, around here I am the law."178

In November 1995, the Pennsylvania Supreme Court overturned the commonwealth court ruling by a vote of 5-0, allowing Thermal Pure to reopen. ${ }^{179}$ In its decision, the supreme court ruled that the commonwealth court lacked jurisdiction over the matter, and that the Waste Disposal Act merely addressed incineration and other disposal, and did not cover sterilization-Thermal Pure's process. ${ }^{180}$ Accordingly, the permit was deemed valid.

The decision exists under a cloud of illegitimacy for many Chester residents. According to CRCQL, the supreme court's initial use of the King's Bench power, and its ultimate disposition of the case, may have been influenced by the firm responsible for the recent proliferation of waste sites in Chester. Pennsylvania Supreme Court Justice Stephen Zappala is the brother of a partner in Russell, Rea, and Zappala, owners of most of the facilities located in Chester. ${ }^{181}$ Justice Zappala recused himself from the Chester case, but CRCQL believes he "exercised his influence" by "convincing the court to use the outdated King's Bench statute." ${ }^{182}$ While this accusation has yet to be proven, ${ }^{183}$ the appearance of impropriety sounded the death knell for CRCQL's belief that the law would provide justice for people like themselves. In their eyes, this was yet another example of the structural power of racism. As Zulene summarized, "racism is real," and it is "the determining factor [in] whether or not you're going to get justice." Jerome Balter, in contrast, believes the community relied too heavily on the legal system. "There is a reliance on legal action, and no matter how much the lawyer says 'don't count on it,' they count on it.".184

CRCQL learned a powerful lesson: While legal action brings muchneeded attention to environmental justice struggles, legal strategies rarely address what is, in essence, a larger political and structural

178. Interview with Jerome Balter, attomey for CRCQL, in Phila., Pa. (Dec. 3, 1996).

179. See Chester Residents Concerned for Quality Living v. Dep't Envtl. Resources, 668 A.2d 110 (Pa. 1995).

180. The Pennsylvania Supreme Court focused on the mass reduction that follows incineration as the determining factor in their interpretation of the Act. As sterilization did not reduce mass, it was not covcred by the Act. See id.

181. See supra Part I.B; see also Brian O'Neill, Zappala Slips His Family Ties, PrTTSBURGH Post-Gazetre, Aug. 24, 1994, at C1 (noting Justice Zappala's admission that he bought securities in Russell, Rea \& Zappala).

182. Russell, Perpetrators, supra note 26.

183. This accusation has been repeated in the press, however. See, e.g., Frank Reeves, Special Power of State Court Challenged, PrtTsburgh Post-Gazetre, July 23, 1995, at Al ("It is another example of the exercise of the 'King's Bench' authority by the court for no apparent reason and where a member of the court, although he has recused himself, has an apparent familial interest in the case.") (quoting Rep. Piccola of Dauphin County).

184. Balter, supra note 178 . 
problem. ${ }^{185}$ As the struggle surrounding the Thermal Pure case illustrates, lawsuits take place in a forum in which the resources of private corporations and government entities far outweigh community resources. ${ }^{186}$ Given their experience with the Pennsylvania Supreme Court, the

Chester community is unlikely to rely solely on legal strategies in the future. In fact, the group realizes that legal strategies, even hopeful ones like the Title VI action they are currently pursuing, are merely "another stone in David's sling," a way to bolster their political struggle for empowerment and inclusion. ${ }^{187}$

\section{Avoiding the Slippery Slope: Becoming Political Actors}

In late 1994, CRCQL became aware of yet another potential hazard targeted for their community. Soil Remediation Systems (SRS) recently had filed a permit application with the DEP to construct a soil incineration facility in Chester. Once again, the community mobilized. Petitions, protests, and a well-attended public hearing sent the message to SRS and the DEP that the community did not want another facility.

Yet again, residents faced questionable tactics employed by the facility proponents. For example, early in the public hearing, a young man from the community stood up and said, "I don't care what they do, I need a job." 188 After the resident spoke, one of Zulene's friendsa man she considered a nephew-approached her and explained what was happening. Pointing to the man who had just spoken, he hugged her and said, "I'll tell you what's up, he's paid. And they paid me too, but I'm not going to talk." This tactic, of course, was not new. In a sense, it was the classic jobs-for-environment tradeoff that faces opponents of hazardous waste facilities. ${ }^{189}$ The facilities were following the time-honored practice of businesses hoping to move into financially ailing communities, and offering financial incentives and increased

185. Many environmental justice advocates view struggles to stop the proliferation of hazardous waste sites as inherently political, not legal, problems. As Luke Cole pointed out, "because someone in the govemment has decided to allow a company to dump in their neighborhood," what is required to change that decision is a "political tool." Cole, supra note 7, at 648. As such, hitigation and most legal strategies are viewed as vehieles for broader political organizing and community empowerment. See Luke W. Cole, Remedies for Environmental Racism: A View From the Field, 90 MrCH. L. Rev. 1991, 1995-97 (1992); see also Derrick A. Bell, Jr., Serving Two Masters: Integration Ideals and Client Interests in School Desegregation Litigation, 85 YALE LJ. 470, 513 (1976) ("Litigation can and should serve lawyer and client as a community-organizing tool, an educational form, a means of obtaining data, a method of exercising political leverage, and a rallying point for public support.").

186. See Cole, Remedies for Environmental Racism, supra note 185, at 1996.

187. See generally Luke W. Cole, Environmental Justice Litigation: Another Stone in David's Sling, 21 FordHAM URB. LJ. 523 (1994).

188. Mayfield Interview, supra note 151.

189. See Bullard, supra note 106 , at $85-86,90-91$. 
employment opportunities. CRCQL was well aware that the community needed more jobs and economic development. Yet the group was unwilling to sacrifice the quality of their homes, neighborhood, and health for the illusory gains the facility promised. Most of the residents had seen enough waste facilities move into Chester to realize the hollowness of such incentives and job offers.

Fortunately, CRCQL had gained powerful allies by this time. In 1992, after decades of Republican party reign that kept "tight control over the city's votes by controlling public funds in such a way that every government function was delivered as a personal favor," the Democratic party overthrew the Republicans in what CRCQL calls "o ne of the most impressive political campaigns in the city's history."190 CRCQL benefited from this change of leadership: the group convinced all five members of the city council to oppose the SRS permit. Moreover, CRCQL, in a meeting with the Secretary of the DEP, convinced the agency to delay the decision until the EPA completed its health study of Chester. ${ }^{191}$ Despite the public outcry, the opposition by the city council, and the EPA's troubling conclusions in its health assessment of Chester, the DEP granted the SRS permit.

As the political tide turned in CRCQL's favor, group members shifted the focus of their political actions. Instead of "reacting to the actions of the industries and the government" and "trying to convince the power brokers to act on their behalf," the residents moved proactively to "cut these industries off at the pass." the residents to the cause. CRCQL's first successful step in this direction was to convince the city council to amend the zoning code so that waste management industries would face more difficulty when attempting to site facilities in Chester. The group then canvassed the city for signatures for a petition to amend the zoning ordinance. They collected 3,000 signatures and presented them to the city council. The council commenced to drag its feet until CRCQL confronted it and said, "If every meeting we have to call all 3,000 people and tell them the ordinance is not signed, we will do that." ${ }^{193}$

In June 1994, the city council passed an ordinance requiring any waste company hoping to locate in Chester to prove that the operation of its proposed facility would not increase overall pollution levels in the city. SRS failed to meet the burden of proof under the ordinance. As a

190. Kelley, supra note 28; see also Hinds, supra note 27 (noting that "Republicans, who outnumber Democrats 2 to 1 in this predominantly black city, have controlled the government since 1866," and characterizing the recent Democratic victory as a "stunning upset," largely attributable to "a grass roots voter-registration drive").

191. See supra Section I.A.

192. Russell, Perpetrators, supra note 26.

193. Mayfield Interview, supra note 151. 
result, SRS lost its DEP permit because it could not get a building license from the city and, thus, failed to break ground by the permit's specified deadline. As one CRCQL member remarked, "Finally, the government was forced to react to the residents, instead of the other way around." 194

\section{E. The Importance of Building Coalitions}

Even before CRCQL's brief victory and stinging legal defeat in the Thermal Pure case, its leaders realized that to be effective, CRCQL needed to have broader appeal. By 1993, the group had become primarily African-American and was represented as such in local media. However, it had not always been that way.

When formed in 1992, CRCQL had two co-chairs: Reverend Strand, from the African-American community, and Monsignor Probaski, head of the local Ukrainian and Polish Catholic congregation. Monsignor Probaski was one of the primary organizers of the Westinghouse demonstration. However, during the demonstration, Probaski's secretary came to Thurlow Street and told him that the Archdiocese in Philadelphia wanted to speak to him right away. Shortly thereafter, Probaski returned to the protesters and insisted they disband. The protesters initially refused but eventually agreed to march down to the facility and then disband. At CRCQL's meeting after the protest, Probaski disclosed that he had received a $\$ 500$ check from Westinghouse to renovate his church. He then told the group that he had ripped up the check and sent it back to Westinghouse. Curiously, the week following the meeting, Probaski resigned as co-chair of CRCQL and withdrew from the group. When he left, so did many of his Ukrainian and Polish parishioners. With the loss of Monsignor Probaski, CRCQL became primarily an African-American organization. Currently, the group is approximately $70 \%$ African American, with the rest of the group consisting of elderly Polish women, Latinos, and whites. ${ }^{195}$

In addition to its changing identity, other events forced CRCQL to reevaluate itself. For instance, during the legal battle against Thermal Pure, CRCQL experienced numerous forms of intimidation. The CRCQL office has been vandalized twice. In one of the incidents, featured prominently in the video Laid to Waste, CRCQL's office was vandalized and "KKK" was scrawled prominently above Zulene's desk. As the group's leader, Zulene received the brunt of inany threats against CRCQL. Zulene recalls a neighbor "telling all the little old ladies I better be careful or else somebody is going to firebomb my house." Additionally, her home and car have been vandalized repeatedly, and

194. Russell, Perpetrators, supra note 26.

195. Mayfield Interview, supra note 151. 
occasionally, she receives expletive-laden threats, including death threats, on her answering machine. To top it off, Westinghouse threatened to bring a $\$ 250,000$ lawsuit against Zulene personally for blocking its trucks during CRCQL's protest. ${ }^{196}$

The loss of many of its non-African-American members, the legal loss to Thermal Pure, and the intimidation tactics used against CRCQL members slowly took their toll. Many group members asked themselves, "How effective are we going to be if this machinery still views us in a [negative] way?"197 CRCQL sought to find a way to rejuvenate itself from the pain of racism that was destroying its effectiveness as a citizens group. To expand is coalition, CRCQL sent out invitations over the Internet to an environmental justice retreat they held at Swarthmore College in February 1995. The conference not only informed and educated students about the concept of environmental justice, it created the Campus Coalition Concerning Chester (C4). Today, this student group consists of students from over fifteen campuses from four states, including nearby Swarthmore College. The purpose of $\mathrm{C} 4$ is to assist CRCQL in its battle to educate and fight against environmental injustice in the Chester community. According to Zulene, CRCQL wanted to get people the decision-makers could "relate to;" if not parents then "let's get the children," the group reasoned. The goal was to "educate the kids and let the kids go home" and ask their parents the kinds of questions confronting the Chester community.

By broadening CRCQL's base, Zulene and other members felt they could both build a more politically sustainable partnership, as well as "take the focus off" CRCQL as an African-American organization. Thus far, according to Zulene, the partnership with $\mathrm{C} 4$ has been "wonderful"-educating people on campus, in Chester, and in surrounding communities, $\mathrm{C} 4$ has also been involved in protests with CRCQL. Soon after C4 was formed, they joined a protest against RR\&Z at the firm's Pittsburgh offices. In the summer of 1995, CRCQL and C4 conducted a door-to-door health survey of Chester, which helped to document the poor public health of the community and to bolster the residents' claims of environmental damage. Their partnership has also spawned the Chester-Swarthmore College Community Coalition. Established by grant money, the coalition encourages college students and

196. The threat of lawsuits against active community members or groups, widely known as "SLAPPS"-Strategic Lawsuits Against Public Participation-has been reported as a growing phenomeuon. See George W. Pring \& Penelope Canan, SlapPs: Getring Sued for SPEAKING OUT (1996). This may or may not have been the motivation behind the Westinghouse threat. Nevertheless, the effect of the threat was to motivate the group into broadening its base.

197. Mayfield Interview, supra note 151. 
faculty to work in the Chester community to establish a broad range of social service programs. ${ }^{198}$

\section{F. Chester Today}

Today, the ebb and flow of toxic assault and political protest in Chester continues. Some siting battles are currently simmering, and others have been resolved. In December 1995, the Cherokee Environmental Group applied for a permit to burn contaminated soil in Chester. Residents once again mobilized to fight the facility and over 200 concerned residents, suburban neighbors, and other interested citizens attended the public hearing held in February 1997. CRCQL's efforts may have paid off. In November 1997, the DEP informed CRCQL that the Cherokee permit had been denied on various technical grounds. ${ }^{199}$ The denial of the Cherokee permit, perhaps not coincidentally, has taken place at a time when CRCQL has achieved other significant victories.

Recently, CRCQL successfully settled an environmental lawsuit, brought under the Clean Air Act, against the county's twenty-year-old DELCORA sewage treatment facility, which receives and treats waste for all of Delaware County. In December 1997, the year-and-a-half-long negotiation between CRCQL, EPA, DEP, and DELCORA, finally came to an end. As part of a consent decree, DELCORA has agreed to a $\$ 320,000$ penalty, divided into two parts: $\$ 120,000$ to go to the EPA and $\mathrm{DEP}$, and $\$ 200,000$ to be used to fund a children's lead-poisoning prevention program that Chester residents will manage. ${ }^{200}$ Settlement discussions with Westinghouse over Clean Air Act violations ended in similar

198. See Monica Yant, From One Man's Strength, a Choir Camp That Chops: Disciplining Voices and Character, PHILA. INQUIRER, July 3, 1997, at A1 (describing a summer camp for the Chester Boys Choir offering tai chi, karate, math and reading, and baseball and swimming classes).

199. In its denial letter, the DEP listed various reasons for denying the waste permit. Among the reasons were the following: (1) the application did not provide complete and accurate information, pursuant to $25 \mathrm{PA}$. CODE $\S \S 287.124-287.125$, regarding the identification of interests and compliance information pertaining to the applicant and related parties; (2) the application did not provide sufficient detail or design information to allow the DEP to approve the method proposed for protecting the facility from a flood and soil erosion, in violation of 25 PA. CODE $\$ \S 202,232,297.106$; (3) the application did not provide sufficient information to allow the DEP to determine adequately the potential for, or the need to mitigate, harm to the surrounding community from noise impacts related to the operation of the facility, in violation of 25 PA. CODE $\S 287.127$; and (4) there was not sufficient information on pre-treatunent, treatment, and post-treatment parameters for each category of waste proposed to be accepted at the facility, in violation of 25 PA. CODE $\S \S 134,287.132$, 297.101. The DEP also denied Cherokee's application for an air permit. See Cherokee Biotechnology Plant Defeated! (visited Feb. 1, 1998) <http://www.envirolink.org/orgs/pen/crcql cherokee_goes_down.html> (CRCQL Web Site) (summarizing the letter).

200. See Victoria Rivkin, Chester Residents Achieve "Environmental Victory:" Unigue Settlement for \$320,000 Calls for Environmental Justice, LEGAL. INTELLIGENCER, Dec. 24, 1997, at 5; see also Ramona Smith, 320G Fine Helps Fight Lead Paint, Phila. Dally News, Dec. I9, 1997, at 28. DELCORA has denied any wrongdoing in the consent decree. Id. 
fashion. ${ }^{201}$ And in January 1998, CRCQL received more good news. A federal court ruled that residents have a "private right of action," under discriminatory-effect regulations, promulgated by the EPA pursuant to Title VI of the Civil Rights Act, to challenge the proliferation of waste treatment facilities on grounds of racial discrimination. ${ }^{202}$ This ruling clears the way for the Chester environmental justice suit, discussed above, ${ }^{203}$ against the Pennsylvania DEP for granting permits to five waste-processing facilities in Chester. ${ }^{204}$

Nevertheless, the political tide may be turuing against CRCQL. In 1996, Republicans regained control of Chester after a mixed reaction to the city's short-lived Democratic administration. ${ }^{205}$ Residents are particularly concerned that the newly elected city council may overturn the recently enacted zoning ordinance.

CRCQL also faces a complex, continuing fight over the importation of waste from three states to feed Chester's massive Westinghouse incinerator. CRCQL scored a major, but short-lived, victory through the demonstration they staged in November 1996 at the State of Delaware's Solid Waste Authority's (SWA) offices. ${ }^{206}$ The SWA recently met to

201. See supra note 19 and accompanying text.

202. See Chester Residents Concerned for Quality Living v. Seif, 132 F.3d 925 (3rd Cir. 1998).

203. See supra Section I.C.

204. Another recent proposal was the siting of a pet crematory in Chester. When residents learned of the proposal, they began to educate the community and successfully rallied significant opposition to the facility. In January 1997 , the veterinarian withdrew the permit at a zoning committee hearing. See Accomplishments of $C-4$ and the Chester Residents Concerned For Quality Living (visited Nov. 9, 1997) <http://www.envirolink.org/orgs/pen/crcql/accomp.html> (CRCQL Web page).

205. The tumover may be attributable in part to both low voter turnout, not suprising in lowincome communities of color, and to the tumultous reign of the Democratic administration. See, e.g., Dan Hardy, Chester Mayor Says Council ls Usurping Power, PhILA. InQuIRer, July 8, 1992, at B1 (reporting that the Democractic mayor, Barbara Bohannan-Sheppard, sued four city council colleagues and the city solicitor, contending they usurped her powers to manage her own administration); Dan Hardy, Council Coalition Keeps Chester Mayor on Outside, PhlLA. InquIRER, Apr. 30, 1992, at B4 (reporting that the city eouncil intensified its assault on the Democratic mayor, stripping her of much of her staff and filling council vacancies with Republicans; this move was the latest in the escalating conflict between the mayor and the city council-a struggle that virtually paralyzed city government). How much the tide is turning against CRCQL is unclear. Despite the fact that the Republican mayor of Chester announced his full support of the Cherokee permit application, that permit was denied.

206. Demonstrators described the protest as "unorthodox." According to its participants, the number of protesters never exceeded twenty individuals, and the demonstration was staged in an industrial park far from regular traffic. CRCQL and C4 mcmbers marched on the street in front of the Authority's offices, demanded a meeting with SWA to discuss waste shipments to Chester, and probably were noticed only by the Waste Authority personnel. Barely an hour passed before SWA officials met with the protesters. They agreed to meet later in the month to discuss Chester's residents' concerns. At this meeting, CRCQL presented SWA with a record of Westinghouse's emission violations. SWA expressed genuine surprise at the long list of transgressions, which included the emission of some pollutants at levels exceeding what is deemed safe for the surrounding community. See Andy Murray, Chester Residents and Supporters Protest in Delaware (visited Nov. 9, 1997) <http://www.envirolink.org/orgs/scac 13/c4/dswa.html> (C4 Web Page) (on file with author). 
reconsider its export of 225,000 tons of trash per year to the Westinghouse incinerator. In January 1997, the SWA, whose shipments accounted for $25 \%$ of the incinerator's waste stream, voted to discontinue its shipments to the Westinghouse incinerator. Those responsible for feeding the Westinghouse incinerator did not remain idle, however. After the incinerator was sold to new owners, the SWA reversed its decision and signed a new contract in May 1997 with the incinerator's new owners, Ainerican Ref-Fuel. Under this agreement, 300,000 tons of waste per year may be burned at the Chester incinerator. ${ }^{207}$

Despite the recent and potential setbacks, CRCQL has created a venerable legacy-it is now a political force to be reckoned with in Chester. What began as a small group of residents concerned with their quality of life and their health, has grown into an organization with the power to engage decision-inakers on issues that fundainentally affect the residents' material livelihood. Indeed, CRCQL's biggest victory may be that it is a cohesive, healthy group and is still fighting in coalition with C4. A self-taught community organizer, Zulene Mayfield recognizes that the importance of CRCQL's struggle goes beyond the individual victories and defeats in their campaign against the toxic facilities in Chester. "Historically, black people haven't realized the power they have. The people who have realized it, who have the knowledge, have to teach the others. We have to start using our own power."208

\section{$\mathrm{V}$}

PURSUING ENVIRONMENTAL JUSTICE:

Siting Process Reforms, Strong Participatory Democracy, and TRANSFormative Politics

The Chester experience suggests that distributive paradigms of justice are merely a starting point in understanding the phenomenon of environmental injustice. CRCQL began its struggle out of concern about the accumulation of hazardous waste facilities in their community and the effects those facilities had on the comınunity's quality of life-the trucks, dust, noise, and odor. As their efforts to find out more about the facilities in their community progressed, their strnggle became more multi-faceted. In the end, their resistance was as much about the legitimacy of decision-making processes which fundamentally affect their lives as it was about the outcomes of those processes.

Because environınental decision-making processes are neutral toward existing social inequalities, I have argued that they reproduce these

207. See Murray, supra note 206; Urgent Action!-Delaware Solid Waste Authority Votes to Continue Burning Delaware Garbage in Chester, PA, Release (Green, Del., Bear, Del.), May 1, 1997, at 1-2.

208. MENDeL-ReYes, supra note 17 , at 158 (citation omitted). 
inequalities in the environmental context. As Chester illustrates, the very social and structural constraints that operate in the larger world continue to constrain individuals in the environmental decision-making process. Because of their economic, social, and political isolation, Chester residents, like other low-income people of color, feel that they are viewed and treated as marginal to decision-making processes. In addition, a disparity in available resources persists in counmunities such as Chester because they "enter the fray with less information and specialized knowledge concerning the legal, technical, and economic issues involved."209 Moreover, though inany federal and state environmental laws promise participatory decision-making, Chester illustrates the failure of such laws to include disaffected communities in environmental decisions.

Can reforms in the environmental decision-making process address the problems faced by Chester residents? President Clinton's Executive $\operatorname{Order}^{210}$ and various state laws ${ }^{211}$ indicate that policy-makers are seriously beginning to consider such reforms. In this Part, I will discuss some of these reforms and their potential to achieve "environmental justice" in places such as Chester. ${ }^{212}$ Even in spite of the most effective siting process reforms, direct grassroots participation and organization strategies continue to be necessary. The real success of the grassroots movement for environmental justice will be in creating an ongoing role for community participation in a variety of decisions that affect residents' lives.

\section{A. Grassroots Experiences and Siting Process Reforms: Taking Social Structure Seriously}

Many types of siting process reforms have been proposed and enacted at the state and local levels. Perhaps the most common aspect of these reforms is their effort to control or influence the distribution of hazardous waste facilities. Distributive models of environmental justice

209. Eileen Guana, The Environmental Justice Misfit: Public Participation and the Paradigm Paradox, 17 Stan. Envtl. L.J. 3, 14 (1998).

210. Exec. Order No. 12,898, 59 Fed. Reg. 7,629 (1994) (requiring each federal agency to "make achieving environmental justice part of its mission;" to comply, agencies must issue detailed reports outlining their plan to eliminate racially disparate environmental effects).

211. States that have passed environmental justice legislation include Alabama, Arkansas, Florida, Georgia, Louisiana, Maryland, and North Carolina. See A LA. CODE § 22-30-5.1 (1990); A RK. Code ANn. §§ 8-6-1501 (Michie 1993); Fla. Stat. ANn. §760.85 (West 1996); GA. Code ANN. § 12-8-25.4 (Harrison 1996); LA. Rev. Stat. AnN. § 30.2011(D)(5) (West 1996); MD. Code ANN. Art. 41, § 18-315 (1997); N.C. GEN. STAT. § 160A-325(a) (1994).

212. It should be noted that it is beyond the scope of this Article to account for and analyze fully the realm of proposed and potential siting process reforms. There is a great deal of activity on both the state, local, and, to a lesser extent, federal Ievels regarding siting process reforms. Most of this Article's discussion pertains to reforms that have been recently proposed or have become law. 
are extremely attractive because they seem to get right at the heart of the empirical evidence. They aim to stop the disproportionate impact of LULUs in any given community, particularly if that community already hosts a similar facility. ${ }^{213}$ However, if environmental racism or injustice is partly a manifestation of larger structural inequities, then distributive remedies alone may not be enough. As commentators such as Vicki Been have correctly pointed out, because of post-siting economic and social processes, merely redistributing or fairly distributing LULUs may only re-create a pattern of disproportionate siting. ${ }^{214}$ The one caveat to this broad dismissal of purely distributive solutions is that if siting process reforms were to impose a physically proportional distribution among communities, the pattern of maldistribution would not be recreated because every community would, or could, eventually host a hazardous waste facility or other LULU. As such, "the incentive to move away from a LULU would be reduced because no community would be immune from LULU siting."215

However, even a perfectly proportional distributive scheme would not address many of the problems confronting communities such as Chester in the environinental decision-making process. As in framing environmental injustice, distribution is merely a starting point when conceptualizing what environmental justice would entail. Without nore, a purely distributional scheme does nothing to address the process for siting even a single facility in a scheme which simply limits the number of facilities in a given area. First, it is not clear what role the affected community would play in picking the first, or only, facility in such a scheine. What role would community choice and its assessment of the burdens and benefits of a given facility play in determining whether to locate that facility in a given area? Second, and somewhat related, is the

213. See, e.g., ARK. CODE ANN. \& 8-6-1501 (Michie 1993) (creating a rebuttable presumption against permitting a "high impact solid waste management facility" within twelve miles of any existing "high impact solid waste management facility"); GA. CODE ANN. § 12-8-25.4 (Harrison 1996) (prohibiting the permitting of any solid waste handling facility within an area which already includes all or a portion of three or more landfills in a two-mile radius).

214. As Been explains:

For example, assume that on a given date, all LULUs then needed were dispersed 'fairly' throughout society. Wealthier individuals would respond to the distribution by moving away from LULUs. Consequently, sites located in wealthier areas would eventually be surrounded by a ring of land deserted by wealthier families. The LULU would cause property values in that ring to be lower than in surrounding areas. The ring would then become a ghetto of lower income households. In short, the pattern of disproportionate siting would be re-created.

Been, supra note 69, at 1018 (also noting various arguments and empirical evidence which cast considerable doubt on the likelihood of this particular scenario occuring).

215. Id. at 1020 . Some environmental justice legislation seems to embrace this approach. For instance, Alabama prohibits the siting of more than one "commercial waste facility or disposal site" in any given county. A LA. CoDE $\$ 22-30-5.1$ (1990). Of course, this type of legislation does not prevent other types of facilities or LULUs from being sited in a county. 
question of what criteria would, or could, be used in choosing even one facility. Without some guidance, low-income communities of color could very well end up with more burdensome facilities than more privileged communities, even when the number of facilities is limited. ${ }^{216}$ For instance, while waste facilities were located elsewhere in Delaware County, the facilities with the capacity to process greater amounts of waste were located in Chester. ${ }^{217}$ Hence, it is necessary to pay attention to the process of siting facilities even in a scheme which heavily controls the ultimate distribution of those facilities.

Two trends in environmental justice policy-making may potentially address the issue of fairness in a siting process in which distributive outcomes are heavily regulated. The first trend attempts to factor community choice explicitly into the siting process, even where a proportional distribution of facilities is sought. For instance, an Arkansas statute creates a "rebuttable presumption" against permitting the construction or operation of a "high impact solid waste facility" within twelve miles of an existing "high impact solid waste facility."218 This presumption can be rebutted, among other ways, if "incentives have prompted the host community to accept the siting of the facility."219 This type of

216. Since different facilities contain varying benefits and burdens, and different communities are differently situated, the question of how facilities will be distributed amongst communities remains. See, e.g., Been, supra note $69,1033-40$ (discussing problems with measuring and distributing burdens and benefits of different facilities). For example:

[t]wo neighborhoods hosting identical hazardous waste treatment plants... might bear different burdens if the basis for comparison is health risk, because the geology or transportation networks or composition of the workforce of one area could make one plant somewhat riskier than the other .... When the LULUs being compared are different, such as a prison and a sludge treatment plant, comparisons will require agreement on how different criteria are to be weighted or reduced to some common metric such as dollar loss. Whether and how to translate burdens such as health risks to monetary terms is.... a controversial issue.

Id. at 1033-34.

217. See Staples, supra note 9.

218. ARK. CODE ANN. § 8-6-1504(a)(1) (Michie 1993). A "high impact solid waste management facility" includes "any solid waste landfill, any solid or commercial hazardous waste incinerator, and any commercial hazardous waste treatment, storage or disposal facility." Id. § 8-6-1502(1)(A). This defintion seems to exclude as much as it includes. It excludes the following: recycling or compost facilities; waste-tire management sites; solid waste transfer stations; solid waste landfills which have applications pending to expand their services or capacity; facilities dedicated solely to the treatment, storage, or disposal of solid and hazardous waste generated by a private industry if the private industry bears the expense of operating and maintaining the facility; facilities solely dedicated to a response action at a location listed by the state or federal government as a hazardous substance site; existing facilities operating under the interim status of the federal Resource Conservation and Recovery Act; and existing hazardous waste facilities under RCRA or the Arkansas Hazardous Waste Act which expand either through increased acreage, provision for additional services, or increased capacity. See id. § 8-6-1502(1)(B).

219. Id. Such incentives could include, without limitation: increased enployment opportunities, reasonable host fees not to exceed the prevailing state average, contributions by the facility to the community infrastructure, coinpensation to adjacent individual landowners for any assessed decrease in property values, or subsidization of community services. See id. § 8-6-1504(b)(2). The presumption 
rebuttable presumption ostensibly preserves community choice in the siting process, appealing to the communities' self-determining impulses to make their own decisions whether to accept a controversial facility. However, allowing the presumption to be rebutted by evidence of incentives may not constrain choice enough, given the current structural disadvantages of communities such as Chester. Proffers of increased employment opportunities and host fees will often be subject to the charge of environmental blackmail. ${ }^{220}$ It is precisely the poorest communities which will have the greatest incentives to site such a facility. This reliance on evidence of incentive thus reinforces the original vulnerability of poor communities which the presumption was designed to address. Without technical support from the state agency or an assurance that technical experts have consulted with the community about the potential social and economic hazards of the proposed facility, the community's choice may remain under a cloud of suspicion.

Another policy trend which might make distributive remedies more responsive to the concerus of disaffected communities is the adoption of so-called soft criteria in the siting process. For instance, decision-makers considering whether to issue a permit for another waste facility in Chester would be able to take into account its falling property values, cumulative health risks, and other costs existing facilities inpose on the community. Environmental risk assessment and management are as much social and political issues as they are legal or technical issues. ${ }^{221}$ Therefore, in addition to technical criteria-proximity to wetlands, geology of the site, impact on ground water, and impact on healthnormally considered in assessing the inpact of a proposed facility on the host community, soine state statutes and proposed bills require or allow decision-makers to give weight to social and political factors. ${ }^{222}$

can also be rebutted if "no other suitable site for such a facility is available within the regional solid waste management district because of the restraints of geology or any other factors listed [in the technical assessment criterial." Id. at § 8-6-1504(b)(1). See also H.B. 1195, 61st Leg., 2d Sess. (Colo. 1998) (creating identical presumption, rebuttable upon evidence that the host community "desires" the facility because of incentives offered by the facilities and evidence that no other suitable site is available).

220. See Bullard, supra note 106, at 83-84 (explaining that minority communities are often vulnerable to economic inducements and may minimize their opposition to sitings whose risks might outweigb their benefits because these communities are beset by rising unemployment, extreme poverty, a shrinking tax base, and a decaying business infrastructure).

221. See Daniel J. Fiomo, Environmental Risk and Democratic Process: A Critical Review, 14 Colum. J. ENvTL. L. 501, 503-04, 512-14 (1989); Joseph P. Tomain, Distributional Consequences of Environmental Regulation: Economics, Politics, and Environmental Policymaking, 1 KAN. J.L. \& PuB. Pol 'y 101, 110 (Summer 1991) (arguing cost-benefit analysis is deficient because it obscures sociopolitical norms); Daniel A. Farber, Environmentalism, Economics, and the Public Interest, 41 StaN. L. Rev. 1021, 1043 (1989) (reviewing Mark Sagoff, The Economy of Earth (1988)) (arguing that "cost-benefit analysis is misused to provide technocratic solutions to fundamentally political questions").

222. See Tarlock, supra note 113, at 149-50. 
These social factors can include consideration of the socioeconomic status of the host community, community perceptions, psychic costs, the potential for change in property values, the presence of other facilities in the community, and the cumulative risks presented from other sources in the host community. ${ }^{223}$

The main problem with soft criteria, however, is that often there is no guidance as to the weight decision-makers should, or can, give to these factors in the siting process. ${ }^{24}$ More often than not, administrators retain considerable discretion, allowing for the possibility that these criteria will be ultimately iguored in the final decision.

Even with the incorporation of community input and soft criteria into the siting process, there might still be a risk that low-income communities of color and their concerns will not be treated with dignity and respect in the decision-making process. State administrative agencies still have almost complete discretion and control over the decision, and the community is relegated to a tangential role. For reasons discussed in the next Section, environmental justice for communities such as Chester must also include policy reforms which treat those most at risk from proposed facilities as partners in an openly deliberative decision-making process.

\section{B. The Promise of Participatory Democracy: Taking Process Seriously}

Environınental decision-making, as with much of administrative decision-making, partly gains its legitimacy from the democratic norm embedded in much of environmental law, ${ }^{225}$ particularly its public participation provisions. ${ }^{226}$ Public participation provisions promise to

223. See, e.g., ALA. CODE § 22-30-5.1(d) (1990) (requiring selection committee to consider and include in its written report the "social and economic impacts of the proposed facility on the affected community, including changes in property values, community perception and other costs"); KY. REv. StAT.ANN. \& 244.855(1)(c) (Michie 1995) (requiring agency to consider "community perceptions and other psychic costs"); N.C. GEN. STAT. § 160A-325(a) (1996) (requiring considerations of "socioeconomic and demographic data" in selecting or approving a site for a new sanitary landfill that is located within one mile of an existing sanitary landfill); H.B. 518, 90th Leg., ist Sess. § 15 (IIl. 1997) (requiring a community impact statement "written in plain language and limiting the use of technical terms" to provide information about, among other things, "the presence of any other existing toxic chemical facilities and hazardous waste sites in the affected community"); H.B. 2103, 1st Sess. $§ 7$ (Tex. 1997) (requiring consideration of "cumulative risks," including the combined level of noise, odor, and other impacts, in an administrative proceeding involving the siting or expansion of operation of a facility in an area where other facilities are located).

224. But see, e.g., H.B. 518, 90th Leg., Ist Sess. § 15 (Ill. 1997) (instructing local permitting authority to "give great weight to the community impact statement when making a final decision regarding the issuance of a permit").

225. See, e.g., Fiorino, supra note 221, at 523-30; Douglas R. Williams, Environmental Law and Democratic Legitimacy, 4 DUKE ENvTL. L. \& PoL'Y F. 1, 6-31 (1994).

226. See, e.g., Luke W. Cole, Macho Law Brains, Public Citizens, and Grassroots Activists: Three Models of Environmental Advocacy, 14 VA. ENvTL. L.J. 687, 689-91 (1995) 
include the public in the decision-making process by providing them, at least, with notice about a proposed siting and an opportunity to comment on the proposed action. ${ }^{27}$ However, precisely what type of democratic process or community participation does or should underlie environmental decision-making processes has never been established. The model that best describes current participatory norms in environmental law is a pluralistic, interest-group representation model, which, in practice, tends to exclude or silence some groups. ${ }^{228}$

(summarizing broadly the public participation provisions in federal and state environmental laws); Bradford C. Mank, Environmental Justice and Discriminatory Siting: Risk-Based Representation and Equitable Compensation, 56 OHо ST. L.J. 329, 370 (1995) (noting that "[m]ost commentators, including the author, have argued in favor of increased public participation in environmental decision making primarily because such participation is consistent with democratic values and because administrative decision making has its own limitations"); Ellison Folk, Comment, Public Participation in the Superfund Cleanup Process, 18 Ecology L.Q. 173, 178-80 (1991).

227. A typical administrative process used in local land-use decisions is as follows:

Before a company applies for a local land-use permit, it sends a letter of intent to the local agency. The agency then holds a pre-application hearing. The purpose of this hearing is to explain the project and the permitting process. Next, the company files a formal application with the agency. At this point, the agency evaluates potential environmental effects of the project. If the project will have a potentially significant effect on the environment, state law directs the agency to prepare an environmental impact report (EIR). The local agency holds a meeting to determine the scope of the EIR. This scoping meeting is open to the public, but is often attended exclusively by officials from other governmental agencies. The agency then prepares an EIR (or contracts with a consultant to produce such a report) detailing the potential effects of the project. This EIR is circulated for public comment to anyone requesting it. Thereafter, the local agency prepares a response to public comments to anyone requesting it. Local agencies will often hold public hearings on the EIR. Finally, the local agency will decide whether to permit the project, theoretically basing its decision on the EIR and public comment. If a proponent or opponent of the project is unhappy with that decision, he or she can then file a lawsuit.

Cole, supra note 226, at 692-93.

228. See Fiorino, supra note 221 at 525-29. After reviewing the participation movement and its legacy in environmental law, Fiorino explains:

Effective participation requires organization, resources, and professional representation. Participation at the national level typically is indirect, because it is mediated through voluntary associations organized to assert related interests. Often participation is equated with opposition. The public is placed in a reactive posture: comments are noted, views are heard, opportunities are presented. But we rarely see a sharing of power or the codetermination of policy. The process concedes a marginal role to the individual citizen. Genuine infiuence is granted reluctantly, minimally, and to interests with the capacity to obstruct decisions later. Participation is biased, because it draws on groups with the nceded information, coinpetence, and resources. It is skewed in the way that it solicits the participation of those with the most to lose or the greatest intensity of feeling on an issue.

Id. at 529; see also Young, supra note 3, at 183-84 ("Where some groups are materially privileged and exercise cultural imperialisun, formally democratic processes often elevate the particular experiences and perspectives of the privileged groups, silencing or denigrating those of oppresscd groups."); Gauna, supra note 209, at 25 (noting that "public hearings for permits and other discrcte environmental decisions, notice and comment requirements for mlemaking proceedings, and citizen advisory groups to the EPA are generic institutional mechanisms intended to promote access and equal footing among, in agency parlance, 'stakeholders"); id. at 37 (noting that undue reliance on a pluralistic model of participation is problematic because "preferenccs are defined by the relative power of self-interested subjects" and such preferences "may be distorted by existing inequalities, poorly construed as a result of exclusion and unequal political clout"). 
Grassroots experiences like those in Chester suggest the need to rethink the theory and practice of participatory decision-making processes in environmental law. As environmental justice advocates have argued, meaningful participation by those most affected by environmental decisions is a crucial component of assessing the fairness of environmental decisions. ${ }^{229}$ When communities receive inadequate notice or receive information that they cannot understand the participatory nature of the decision-making processes is called into serious question. ${ }^{230}$ However, even when decision-making processes are open, formal access may not be enough. For instance, where inclusion in the decision-making processes is merely co-optive of community opposition and/or makes no difference in the decisions, the pluralistic nature of the process is in doubt. ${ }^{231}$ More fundamentally, agency decision-makers' overemphasis on technical assessments of the proposed facility, to the exclusion of socioeconomic assessments, add to the perception that public participation has little, if any, effect on influencing agency actions in siting decisions. ${ }^{232}$ Given current social and structural inequalities, problems of accountability and special interest influence are likely to render traditional participatory processes problematic in racially and economically

229. See Robert D. Bullard, Introduction, in U NEQUAL PRoTEction, supra note 1, at xvii ("What do grass-roots leaders want? These leaders are demanding a shared role in decision-making processes that affect their communities. They want participatory democracy to work for them."); Deeohn Ferris, Communities of Color and Hazardous Waste Cleanup: Expanding Public Participation in the Federal Superfund Program, 21 FordHAM URB. LJ. 671, 675 (1994) (suggesting that limited public involvement in cleanup decisions may explain why a National Law Journal study found that cleanups under the Superfund program took longer in minority and low-income communities); Torres, supra note 112, at 453-54 (advocating redefinition of the "regulatory culture" to include affected communities in the decision-making process).

230. See, e.g., El Pueblo Para el Aire y Agua Limpio v. County of Kings, No. 366045, 22 Envtl. L. Rep. 20357 (Cal. Super. Ct, Sacramento County, Dec. 30, 1991) (overturning the county's permit for a toxic waste incinerator partly because the county failed to provide a largely Latino community with Spanish translations for the environinental reports and public hearing docuinents).

231. See Cole, supra note 226 , at 701 ("IC]ommunities learn the hard way that the public participation process is not designed to hear and address their concerns, but instead to manage, diffuse, and ultimately co-opt community opposition to projects."); Ferris, supra note 229, at 675 (1994) (argning that public participation requirements in environmental statutes are "largely intended as community relations efforts" rather than substantive deliberative processes); Lawrence E. Susskind, Overview of Developments in Public Participation, in Public Participation IN Environmental Decisionmaking 2 (Elissa C. Lichtenstein \& William T. Dunn eds., 1994) (noting that final administrative procedures are "unlikely to be affected by" citizen input at public hearings, and that "[c]losure, or agreement, is reached by elected or appointed officials behind closed doors").

232. See Ann Bray, Comment, Scientific Decision Making: A Barrier to Citizen Participation in Environmental Agency Decision Making, 17 WM. Mrrcherl L. Rev. 1111, 1115 (1991) (recounting results of a study which concludes that "the failure of citizens to influence environmental decision makers is directly related to the inability of the scientific decision-making process to accommodate cultural and political rationality in agency decision making"); see also James S. Freeman \& Rachel D. Godsil, The Question of Risk: Incorporating Community Perceptions in Environmental Risk Assessments, 21 Fordham URB. L.J. 547 (1994). 
disadvantaged communities. ${ }^{233}$ As long as the decision-making process is neutral towards these structural barriers to adequate participation, it will continue to replicate them, and the process will never be seen as legitimately democratic to those who are most affected by the decisions. ${ }^{234}$

To be sure, as the Chester struggle illustrates, disaffected communities recognize the limits of traditional participatory processes. Organizations such as CRCQL are forced to look outside of these processes to ensure that their views, their concerns, and their expertise about problems in their communities are ultimately represented in the final decision. ${ }^{235}$ Their need to go outside of these processes, as CRCQL did, suggests that new norms or models of participation may be needed in order to legitimize environmental decision-making processes so that all affected communities have an opportunity to participate meaningfully.

A crucial policy reform toward achieving environmental justice for communities such as Chester is to move from the current pluralistic, interest-group representation model to a more deliberative model of participation in the siting process. Shared knowledge, collective decision-making, and free and equal discourse among participants, rather than formal access and the aggregation of pre-existing preferences should form the foundation for the deliberative process. ${ }^{236}$ Toward that end, certain questions should be asked when evaluating the legitimacy of participatory decision-making processes in the siting process: (1) whether those most affected by the decision either have an opportunity to participate directly or to be represented in each phase of the decision-making process; (2) whether the community is informed

233. See supra note 228.

234. See Mank, supra note 226, at 369 (noting that "because wealthy people have greater access to lawyers, lobbyists, and the media, a key question is whether any siting process that incorporates public opinion can temper the tendency to site facilities where people are relatively powerless").

235. Some of the techniques employed outside of formal public participation processes have been passed down from other social movements-such as public protests, demonstrations, coalition building with more powerful groups, letter-writing campaigns, and developing technical expertisewhile others are distinct to environmental justice struggles-such as "toxic tours" of heavily polluted low-income and/or minority neighborhoods to educate the media, decision-makers, and other supporters. See, e.g., Cole, supra note 226, at 697-701; Peggy M. Shepard, Issues of Community Empowerment, 21 FoRDHAM URB. L.J. 739, 753 (1994).

236. As Seyla Benhabib explains:

According to the deliberative model of democracy, it is a necessary condition for attaining legitimacy and rationality with regard to collective decision-making processes in a polity, that the institutions of this polity are so arranged that what is eonsidered in the common interest of all results from processes of collective deliberation conducted rationally and fairly among free and equal individuals. The more collective decision-making processes approximate this model, the more it increases the presumption of their legitimacy and rationality.

Seyla Benhabib, Toward a Deliberative Model of Democracy, in Democracy AND DifFerBnCE, supra note 136, at 69; see also Jürgen Habermas, Three Normative Models of Democracy, In DEMOCRACY AND DIFFERBNCE, supra note 136, at 21 (describing the "deliberative model of politics" and contrasting it with liberal and republican models). 
adequately about all available information regarding the proposed action and whether such information is accessible; (3) whether the agency is responsive to community knowledge and concerns; and (4) whether decision-making power and influence is shared between those asked to bear the greatest risk, those who stand to benefit the most, and the institutions, administrators, and technical experts responsible for the ultimate decision. $^{237}$

What would such a process look like? While it is beyond the scope of this Article to construct such a process, the public participation reform that best approximates the model I have in mind was contained in the proposed Superfund Reform Act of $1994 .{ }^{238}$ Even though this bill had a wide base of support, it ultimately failed. It required the EPA to provide "early, direct, and meaningful community involvement in each significant phase of the response activities taken under the Act." ${ }^{239}$ To do this, the bill eased the requirements for technical assistance grants, required the involvement of affected citizens earlier and more often in all stages of cleanup, provided for more public meetings, and established citizen information and access offices. ${ }^{240}$ The bill also expressly required the EPA to make its information accessible and suitable for the unique cultural needs of the affected community. ${ }^{241}$

The most significant aspect of this legislation, in terms of deliberative democratic principles, was the creation of Community Working

237. See Daniel $S$. Iacofano, Public Involvement as an Organizational Development Process 13 (1990) (describing the criteria with which to evaluate meaningful public participation as public interest representation, information exchange between the public and the agency, public interest mediation and acceptability, and agency responsiveness); Fiorno, supra note 221, at 536-39 (discussing the "participatory ideal" based upon participatory theorists such as B. Barber, J. Mansbridge, and C. Pateman); Pub. Participation \& Accountability Subcommittee, Nat'1 Envtl. Just. Advisory Council, Model Plan for Public Participation (visited Jan. 14, 1998) <http://www.prcemi.com:80/nejac/publicat.html> (reporting public participation checklist containing thirty-five specific recommendations for environmental agencies, including the recognition of community and indigenous knowledge, creation of an atmosphere of equal participation, creation of co-sponsorship and co-planning relationships, and a recognition of environinental justice stakeholders as full partners).

238. See H.R. 3800, 103d Cong. (1994); S. 1834, 103d Cong. 2d Sess. (1994). See John H. Cushman Jr., Congress Forgoes Its Bid to Hasten Cleanup of Dumps, N.Y. Times, Oct. 6, 1994, at A1 (reporting that the bill gamered support from oil, chemical, and insurance industries, labor and environmental groups, and state and local governments).

239. S. 1834, 103d Cong., 2d Sess. \$102(c) (1994). The bill actually refers to the president in many places, but pursuant to an executive order, the president has delegated much of his authority to the EPA. See 42 U.S.C. \$ 9615 (1994); Exec. Order No. 12,580, 52 Fed. Reg. 2923 (1987).

240. See S. 1834, 103d Cong., 2d Sess. (1994); see also Richard E. Bartlet \& David E. Polter, Summary of the Proposed Superfund Reform Act of 1994, 25 ENv'T REP. (BNA) 608, 611 (July 29, 1994).

241. See S. 1834, 103d Cong., 2d Sess. § 101(c) (1994) (requiring that information be presented orally and distributed in foreign languages where appropriate). 
Groups (CWGs) at each site. ${ }^{242}$ The bill established the following procedure: the EPA would nominate citizens from the affected community to sit on the CWG; the membership on the CWG would be limited to twenty members; ${ }^{243}$ and the two main functions of the group would be to serve as a local information clearinghouse and as an advisory group to the EPA. ${ }^{244}$ The CWG membership could include a broad variety of people, ranging from persons living or owning property immediately adjacent to the facility, members of the local medical community, local officials, facility workers, facility owners, local businesses, members of public interest groups, persons potentially affected by releases from the facility, and representatives of Native-American tribes. ${ }^{245}$ The EPA was urged to consider seriously the CWG's recommendations and respond to the working group's concerns and proposals in writing. ${ }^{246}$

Despite the potential for this type of reform to enhance meaningful public participation in communities such as Chester, there are weaknesses imbedded in the proposed bill which go to the very essence of the deliberative model discussed earlier. The first weakness pertains to the level of representation on CWGs. In terms of representation, while the bill sought inclusion from a broad cross-section of affected citizens, it spoke in permissive rather than mandatory terms. The bill provided that it is "appropriate" for the EPA to imclude representation from the above-mentioned groups. ${ }^{247}$ Given the discretion inherent in that provision, the very groups currently left out of decision-making processes could continue to be left out, whether by oversight or otherwise. Moreover, since the bill did not specify the number of persons to be included from each listed category of interests, and given the limit on the size of the CWG, it is quite possible that those most adversely affected by the

242. See S. 1834, 103d Cong., 2d Sess. § 103 (1994). EPA already had experience with community workgroups as part of its own public participation programs, which it initiated before Congressional mandates to involve communities in the cleanup process. The EPA's experiences with these groups, however, has been limited and not as extensive as this bill would mandate. See generally Folk, supra note 226, at 193-212.

243. This limit would address the concern that excessive public participation impedes agency deliberation. See Jim Rossi, Participation Run Amok: The Costs of Mass Participation for Deliberative Agency Decisionmaking, 92 Nw. U. L. REv. 173 (1998). Rossi argues that while threshold levels of participation often improve the quality of agency decisions, participation can, and does, affect ordinary agency decisions adversely. Id. at 179-80, 212-15. For instance, excessive participation may, in the context of the environmental impact statement procedure, create information problems, encourage use of strategic delay and thwart the development of agency programs. Id. at 224-28.

244. See H.R. 3800, 103d Congress, § 103(i) (1994); S. 1834, 103d Cong., 2d Sess. § 103 (1994).

245. Id.

246. See S. 1834, 103d Cong. $2 d$ Sess. § 105 (1994).

247. See H.R. 3800, 103d Cong. § 103(i)(4) (1994). 
decision would obtain only token representation, while others would be better represented..$^{248}$

The second weakness pertains to decision-making power. The CWG would serve an advisory function only. Although the EPA was counseled to be responsive, the agency retained discretion to dismiss or discount a CWG's concerns or recommendations in the final decision. ${ }^{249}$ Hence, not only would the CWG lack decision-making authority, it likely would also lack any influence in the decision-making process.

In short, citizen advisory committees, such as CWGs, are only a first step toward improving communication between environmental decisionmakers and affected communities. If public participation processes in environmental law are to move toward a more deliberative process, even stronger reforms will be necessary. Siting review committees and boards must ensure adequate representation or direct participation of those who will bear most of the risk and burdens inherent in a proposed site. ${ }^{250}$ Moreover, decision-making under a deliberative model should include both a greater degree of agency responsiveness to those most affected by the decision and increased shared decision-making power. When the element of collective deliberation and decision-making is not present, cominunities such as Chester will continue to feel that the "system is stacked and that no amount of participation by itself will change the relations of power that give rise to environmental degradation."251 As long as this sentiment exists in disaffected communities, the call for justice in environmental decision-making will continue to grow louder.

248. Representation can be a key issue in determining whether a proposed public-participation reform is a compelling alternative to the current pluralistic decision-making model in environmental law. See Rossi, supra note 243 , at 244-45. Ideally, within a deliberative model, public-participation requirements should include representatives who are both "empowered to speak for the group they claim to represent" and able to "act for" the group they represent by mediating, rather than merely aggregating, the interests of the group. Id. at 245-46. Representatives would thus "enable individual group members to gain access to the contents of the deliberative agency decision-making process, while also expressing to agency decisionmakers a group position." Id. at 245.

249. However, one of the EPA's administrators did remark that the remedy selection process "could be amended to give commnnity work groups great deference in remedy selection: the agency would have to make a 'strong showing' to ignore the community's recommendation." Mank, supra note 226, at 374 n.259 (quoting Mary Bryant, Environmental Justice Forum, SoNREEL News, July/Aug. 1994, at 8 (reporting a speech by Elliot Laws on April 29, 1994 at the Environmental Justice Forum in Dallas)).

250. Of course, what constitutes a burden or benefit is a complex issue. As one commentator has noted, "In order to compare burdens ... society must be able to identify the winners and losers of a particular siting decision, as well as to calculate their gains or losses with some precision. Unfortunately, the techniques of cost/benefit analysis have not achieved the requisiste level of sophistication." Been, supra note 69 , at 1039 . The fact that current scientific analysis cannot calculate the costs and benefits accurately, in my view, is even more reason to have deliberative decisionmaking processes.

251. Cole, supra note 226 , at 697 (relating the view of many community activists). 


\section{Strong Democracy and the Transformative Politics of the Grassroots Environmental Justice Movement}

Grassroots groups such as CRCQL have not had the time to await reforms in environmental decision-making processes. Even while operating under the influence of various social and structural constraints, Chester residents have been able to construct a direct political strategy and establish a grassroots base to influence environmental decisionmaking in their community. However, as the current situation in Chester indicates, the residents' success remains tentative and subject to the same constraints that threaten to overwhelm their resistance. An everchanging political landscape further frustrates reform efforts. Nevertheless, groups such as CRCQL already have begun to transform environmental politics and the representation of marginalized communities in the environmental decision-making process.

One of the ways in which this transformation is occurring is that groups such as CRCQL are practicing a strong version of participatory democracy, whereby "self-governing citizens ... participate in the talk through which questions are formulated and given a decisive political conception."252 The process of strong participatory democracy in Chester progressed through various stages of evolution, in which they "creat[ed] greater political consciousness among the potential participants, directly confront[ed] entrenched economic and statist powers, present[ed] their cause to the larger public, cultivat[ed] support among various constituencies, and develop[ed] sufficient internal and external resources so that they could mobilize large numbers when necessary." ${ }^{253} \mathrm{CRCQL}$ 's struggle also evolved from a confrontational mode in which they demanded answers from decision-makers, to a more sophisticated deliberative mode which included the mastery of technical language, and finally to a coalition mode in which they drew upon the resources of other citizens. As importantly, CRCQL became an effective political actor in the decision-making process by affecting the local decision-making processes through protesting and lobbying for ordinances.

In the process of building its strong democratic movement, CRCQL created what Harry Boyte and Sara Evans have called free spaces, "settings which create new opportunities for self-definition, for the development of public and leadership skills, for a new confidence in the possibilities of participation, and for wider mappings of the connections

252. Benjamin R. Barber, Strong Democracy: Participatory Polmics for a New Age 196 (1984).

253. PuLIDo, supra note 4 , at 197. 
between the movement members and other groups and institutions." 254 Part of what sustains these free spaces-in which ordinary people move from complainers and victims to participants in the processes which govern their lives-is the realization by local groups that power relationships within a decision-making structure are fluid and contestable. ${ }^{255}$ Once this realization takes hold, as it did in Chester, participants move from a reactive to a proactive mode in which decision-makers respond to their concerns.

What do the strategies of these grassroots groups mean for the future of environmentalism? Grassroots activists, such as the members of CRCQL, create a level of environmental self-determination once nonexistent in their communities. It is not that these communities are just beginning to care about environmental issues. Rather, these communities have come to realize that the mainstream environmental movement has constructed a notion of environmentalism which fails to address the material concerns of low-income communities of color. ${ }^{256}$ Grassroots environmental justice activists recognize this neglect and hope to construct a new meaning of environmentalism, linking environmental preservation to their material environment and community.

The notion of "environment" for environmental justice groups and networks has come to mean "home" and "community."257 These are the places that need to be preserved and protected from pollutants and other harms. This "community preservation" principle ${ }^{258}$ recognizes that the harms resulting from the disenfranchisement of the most vulnerable communities from environmental decision-making are not only health-related, but include non-health-related consequences-such as the reduction of community cohesion and socioeconomic damage,

254. Sara M. Evans \& Harry C. Boyte, Free Spaces: The Sources of Democratic Change in AMerica xix (1986).

255. As Evans and Boyte explain:

If power relationships in many settings are sharply unequal, they also are always contested and mutually transformative. One never simply "acts on" another-any process of action always has reciprocal moments, changing both partners in the drama. Groups of people in society are never simply or completely "powerless"; there are always resources, stratagems, and social and cultural maneuvers available to and used by even those who seem at first appearance most unambiguously victimized. Out of the density and complexity of power dynamics ... relatively autonomous popular activity-what can be called "free spaces"-can be sustained over long periods.

Id. at xvii; see also Winter, supra note 143 .

256. As Regina Austin and Michael Schill explain, "[I]n the view of many people of color, environmentalism is associated with the preservation of wildlife and wildemess, which simply is not more important than the survival of people and the communities in which they live; thus, the mainstream [environmental] movement has its priorities screwed." Regina Austin \& Michael Schill, Black, Brown, Red, and Poisoned, in UNEQUAL Protection, supra note 1, at 58.

257. Cynthia Hamilton, Women, Home \& Community: The Struggle in an Urban Environment, RaCE, Poverty \& ENv'T, Apr. 1990, at 3.

258. See Peter L. Reich, Greening the Ghetto: A Theory of Environmental Race Discrimination, 41 U. KAN. L. REv. 271 (1992). 
resulting from the loss of businesses, homes, and schools. ${ }^{259}$ The initial rallying point for many communities is the destruction of their quality of life-from the invasion of trucks, dust, and noise that accompany the existence of a waste facility in their neighborhood. Only later do residents see the link to actual health effects.

However, to reduce grassroots struggles to a new consciousness about environmental concerns-even as that term is construed broadly - would be a mistake. As Giovanna Di Chiro explains:

The notion that grassroots, community-based, social and racialjustice driven organizations are composed of "new environmentalists" is contested terrain. Questions of the importance of self-representation, definitional clarity, and the agency inherent in "speaking for ourselves" are key issues for movement activists. What is "new" about the environmental justice movement is not the "elevated environmental consciousness" of its members but the ways that it is transforming the possibilities for fundamental social and environmental change through processes of redefinition, reinvention, and construction of innovative political and cultural discourses and practices. This includes, among other things, the articulation of concepts of environmental justice and environmental racism and the forging of new forms of grassroots political organization. ${ }^{260}$

Indeed, the next phase in the transformation of environmental justice participants, and their local communities, lies in forging partnerships and networking with grassroots organizations across substantive areas. ${ }^{261}$ As CRCQL has done in Chester, environmental justice groups are networking with other groups to provide information and technical expertise to grassroots constituencies on various issues of interest to disenfranchised communities. ${ }^{262}$ Because of these networks, residents in margimal communities will continue to shape environmental policy and

259. In rare but remarkable fashion, at least one court has acknowledged the presence of these multidimensional harms. See Bean v. Southwestern Waste Management Corp., 482 F. Supp. 673 (S.D. Tex. 1979), aff'd, 782 F.2d 1038 (Sth Cir. 1986). While rejecting the claim that the government's decision to grant a permit to site a solid waste facility in a minority community was discriminatory, the court nevertheless recognized that the proposed solid waste facility would affect the entire nature of the community-its land values, its tax base, its aesthetics, its inhabitants' health and safety, and its high school located 1,700 feet from the site.

260. Giovanna Di Chiro, Reframing Environmental History: Nature, Environment, and Community in the Environmental Justice Movement 13 (Dec. 2, 1996) (unpublished manuscript, on file with author).

261. See, e.g., Riehard Moore \& Louis Head, Building a Net That Works: SWOP, in UNEQUAL Protection, supra note 1, at 191 (describing the Southwest Organizing Project, a multi-racial, multiissue, community-based organization located in Albuquerque, New Mexico, whose mission is to empower the disenfranchised in the Southwest to realize social, raeial, and economic justice.)

262. See Who Is the Pennsylvania Environmental Network (PEN)? (visited Jan. 8, 1998) <http://www.envirolink.org/orgs/pen/about.html> (describing network of grassroots organizations, ineluding CRCQL, throughout the state of Pennsylvania). 
create more opportunities for community input into the spectrum of policy-making which affect their material conditions. ${ }^{263}$ Only the future will prove whether, and to what extent, these networks can consolidate the power of varied local organizations such as CRCQL and implement an agenda for environmental and social justice for society's most vulnerable members. Until then, the success of groups such as CRCQL suggests that the goal is not out of reach.

\section{CONCLUSION}

This Article has attempted to situate grassroots experiences and struggles at the center of the environmental (in)justice analysis. A close look at the political economy of commuuities such as Chester, Pennsylvania illustrates that racial and class disparities in the distribution of environmental hazards are produced by, and within, a particular system of social relations and structure. Grassroots experiences, such as those in Chester, are crucial to both understanding the social relations and processes underlying distributive outcomes and to evaluating the efficacy of reforms in the siting process.

As Chester illustrates, the environmental injustice phenomenon goes beyond the racial and class maldistribution so well documented in numerous empirical studies. Environmental injustice manifests itself through environmental decision-making processes. Thus, policy-makers should continue to reexamine the foundations of both substantive criteria and participatory processes in reforming the siting process. While current and proposed reforms are a step toward a more equitable siting process, environmental justice in communities such as Chester will require stronger participatory norms in the siting process. Until then, groups such as CRCQL in Chester will continue to build a grassroots base to influence local environmental decision-making processes, even while operating under severe social and structural constraints which render their victories so tentative.

263. As Peggy Shepard, a community activist, eloquently explained:

While it is important to work at the community level to develop viable programs, it is also crucial to build at the community level an advocacy base to bring issues, concerns, needs, and ideas of communities of color to the policy making and decisionmaking process. This strategy allows communities to impact public policy at the front end rather than being in a reactive mode.

Shepard, supra note 235 , at 750 . 
CALIFORNIA LAW REVIEW 